\title{
Sociální vzestup podnikatelů v Rakouském císařství
}

\author{
JAN ŽUPANIČ*
}

The Social Rise of Businessmen in the Austrian Empire

\begin{abstract}
The events of the mid-19th century marked a fundamental change for Central Europe, and the Austrian monarchy was no exception. Although the revolution of $1848 \mathrm{did}$ not mean the permanent entrenchment of liberal changes (which did not occur until the adoption of the February Constitution in 1861), the changes associated with these events fundamentally changed the society of the empire. The end of the division of society and the introduction of equality before the law also significantly affected the social position of businessmen. Before 1848, their legal status was not defined and prestige depended primarily on the place on the traditional ranking of the social hierarchy, which was linked to the holding of a noble title or burgher rights. However, the year 1848 changed this situation and their prestige began to grow thanks to ever closer cooperation with the state and growing political influence. Since the change of the electoral rules to the Chamber of Deputies of the Austrian Imperial Council in 1873, businessmen have even had their own curia (chambers of commerce and trade). At this time, the aristocratic title was no longer a prerequisite for belonging to the elite, but it remained an external symbol of prestige and many businessmen sought it. They saw in it a depiction of their achievements and a fulcrum for the historical memory of their entire family. However, the path to it was not easy and in the case of businessmen it also differed significantly from other social groups of the monarchy.
\end{abstract}

Keywords: Austria-Hungary; nobility; ennoblement; history

DOI: $10.14712 / 23363525.2021 .4$

O podnikatelských elitách $\mathrm{v}$ moderním slova smyslu můžeme $\mathrm{v}$ habsburské monarchii hovořit již v první polovině 18. století, ale po anexi hospodářsky významného Slezska Pruskem v letech 1741 až 1742 jejich počet významně klesl. Sociální skladba podnikatelstva na území habsburské monarchie v protoindustriálním období se navíc od pozdější $\mathrm{v}$ určitých ohledech odlišovala, mj. i proto, že významnou roli mezi podnikateli hrála aristokracie [Matějček 1994: 30; Smutný 1998; Brňovják 2015: 183-184, 201-211].

Kontinuální navyšování počtu podnikatelů, zejména vlastníků manufaktur, velkoobchodníků a finančníků, je spojeno až s osvícenskými reformami ve druhé polovině vlády Marie Terezie [Brňovják 2015: 232-236]. Díky nim Rakouské císařství o půlstoletí později disponovalo početnou podnikatelskou vrstvou, jejíž význam mimořádně vzrostl $\mathrm{v}$ důsledku společenských po roce 1848. Zároveň se začalo pronikavě měnit sociální složení podnikatelstva ve prospěch neurozených osob, mezi kterými rostlo i zastoupení jedinců židovské víry [Hájek - Matoušek 2019: 469-509 (zejména 498-499); Županič - Fiala 2017: 65-75]. Právní postavení podnikatelů bylo před rokem 1848 komplikované. Jako sociální (stavovská) vrstva uznáváni nebyli a jejich aktivity navíc omezovala existence cechů. Pozici

" Prof. PhDr. Jan Županič, Ph.D., Ústav světových dějin, Filozofická fakulta Univerzity Karlovy, Nám. Jana Palacha 2, 11638 Praha 1. E-mail: jan.zupanic@ff.cuni.cz 
jednotlivce tak i nadále určovalo stavovské rozčlenění společnosti a jeho prestiž se primárně neodvíjela od ekonomické základny, ale hlavně od postavení na tradičním žebříčku sociální hierarchie spolené s držbou měštanských práv či šlechtického titulu. ${ }^{1}$

Tato situace se změnila až v důsledku přijetí dubnové ústavy roku 1848, zavedení rovnosti před zákonem a další změn, které radikálně proměnily společnost habsburské monarchie. Šlechtický titul nyní již nebyl předpokladem př́ślušnosti k elitě a prestiž podnikatelů postupně začala narůstat díky jejich stále užší spolupráci se státem a participaci na činnosti nejrůznějších odborných grémií (zejména nově zřízených obchodních a živnostenských komor), spolupráci s novými ministerstvi či soudů, nebo na základě zisku poslaneckých mandátů. Mnozí navíc stále častěji začali veřejné aktivity propojovat $s$ aktivitami dobročinnými, a to jak ve vztahu ke svým vlastním zaměstnancủm, tak širšímu okolí. Mecenátem navazovali na tradice a formy reprezentace, které byly běžné u rodové šlechty a městského patriciátu a tím de facto nastupovali na jejich místa. Nejbohatší dokonce životním stylem napodobovali aristokratické rody, budovali či modernizovali přepychové zámky a nemalou část svých prostředků investovali do nákupu nemovitostí, zejména velkostatků. ${ }^{2}$ Je však třeba zdůraznit, že tímto zpo̊sobem docházelo ke zvyšování prestiže jednotlivců, nikoli podnikatelstva coby stavu.

Toto jednání bývá často $v$ historiografii označováno jako „aristokratizace“, přičemž je třeba podotknout, že se tento termín používá nejednoznačně. Lze souhlasit s Hansem-Ulrichem Wehlerem, že aristokratizace představuje mechanismus přebírání původně jen rodové aristokracii vlastních sociálních vazeb, norem chování a myšlení [Wehler 1995: 718-723]. To ovšem neznamená, že by součástí aristokratizace musel bezpodmínečně být i zisk šlechtického titulu. Už proto ne, že někteří velmi bohatí podnikatelé, kteří se svým životním stylem mohli směle rovnat nejbohatším šlechtickým dynastiím, o nobilitaci nikdy neusilovali, protože pro ně šlechtický titul neměl žádnou hodnotu. ${ }^{3}$ Důvodů k odmítnutí šlechtictví byla jistě celá řada, ovšem jeden z nich považuji za zásadní. Ve vztahu $\mathrm{k}$ Prusku jej vyjádřil Dieter Hertz-Eichenrode, ovšem jednoznačně platí také pro podunajskou monarchii: zisk šlechtického titulu nemohl hrát roli při začlenění jedince a jeho potomků mezi elitu proto, že neexistovala žádná koncepce vytváření (či rekonstrukce) této vrstvy [Hertz-Eichenrode 2006: 676-678]. Jinak řečeno, nobilitace jedince ve skutečnosti na jeho společenském postavení nic neměnila, protože jeho místo na sociálním žebříčku již určovaly jiné faktory.

Často citovaná jsou v tomto ohledu slova rakouského továrníka Josefa Werndla (18311889), jednoho z největších světových producentů zbraní, který měl po zisku (1870) Řádu

1 Komplikovaná byla právní situace zejména u židů, jak ukázal příklad bratrů Porgesů, majitelů velké textilní továrny na Smíchově u Prahy. Když jim bylo opakovaně odepřeno udělení měštanských práv a zrovnoprávnění s křestanskými obyvateli monarchie, získali nakonec roku 1841 šlechtický titul, jenž jim zajistil mimořádně respektované a privilegované postavení i mimo židovskou komunitu. AVA, Adelsarchiv, Porges von Portheim, Adelsakt 1841-1879. Též Županič - Fiala 2017: 61-62.

2 K nákupu velkostatkủ přistupovali ale podnikatelé již v předbřeznové éře. K sociálnímu vzestupu podnikatelů viz: Popelka 2011: 112-133.

3 Z německých (pruských) podnikatelů bývají v tomto ohledu zmiňováni berlínský nakladatel a obchodník Rudolf Mosse (1843-1920), rejdař Albert Ballin (1857-1918) či bankéři Moritz Plaut (1822-1910), Moritz Warburg (1838-1910) a Carl Fürstenberg (1850-1933). Z rakouských bývají nejčastěji zmiňováni velkoprůmyslníci Josef Werndl (1831-1889), Karl Wittgestein (1847-1913), Arthur Krupp (1856-1938) či bankéři a uhlobaroni Isidor (1854-1919), Julius (1856-1932) a Ignaz (1857-1934) Petschekové [Stein 1982: 61-69; Hertz-Eichenrode 2006: 645-679; Drewes 2013: 71-81; Sandgruber 2013: 176-179; Županič - Fiala 2017, 135]. 
železné koruny III. třídy nárok na rytířský titul. O nobilitaci nikdy nepožádal a prohlašoval: „Raději jsem první z měštanů, než poslední ze šlechticů. “4 Podobně se vyjádřil Heinrich Klinger (1832-1902), jeden z největších výrobců textilu v Rakousko-Uhersku. Byl sice držitelem několika čestných titulů a řádů, šlechtictví však odmítl, nebot nechtěl vystupovat jinak, než jako liberální měštan. ${ }^{5}$

Vymezení místa jedince ve společnosti podunajské monarchie totiž nebylo po roce 1848 úplně snadné. Existovala sice rovnost před zákonem, zachováno však zůstalo výjimečné postavení rodové aristokracie, tzv. první společnosti, které určoval Dvorský hodnostní řád (Rangordnung am Hofe seiner k. u. k. Apostolischen Majestät) jednoznačně upřednostňující rodovou aristokracii s náležitým počtem šlechtických předků ${ }^{6}$ před osobami s velkými individuálními zásluhami z neurozených nebo novošlechtických rodin (včetně nejvýše postavených ministrů či diplomatů). ${ }^{7}$ Zbytek společnosti nebyl hierarchizován na základě titulů ani původu, ale de facto na základě individuálního postavení určitého jedince na příčce státní služby. Již v letech 1807 a 1812 byli všichni státní úředníci Rakouského císařství rozděleni do dvanácti tříd (Diätenklassen) z důvodu vytvoření normativ pro jejich finanční ohodnocení a náklady na případné stěhování. Roku 1873 byly dietní tř́dy přejmenován na třídy hodnostní (Rangklassen) a jejich počet snížen na jedenáct. Podle tohoto schématu byli rozčleněni všichni státní zaměstnanci: úředníci, důstojníci, soudci, vysokoškolští a středoškolští profesoři atd. Jedinci do deváté tř́ídy přitom náleželi mezi subalterní a od osmé do páté pak mezi vyšší státní zaměstnance. Top elitu představovali osoby ve čtyřech nejvyšších třídách, kde bychom mohli najít ministry, místodržitele, generály, soudní prezidenty či vyslance. Odrazem tohoto systému byl způsob jejich jmenování: štábní důstojníky (od VIII. hodnostní třídy) a úředníky od VI. hodnostní třídy výše povyšoval panovník, ministrům náleželo právo jmenovat důstojníky nižších hodností a úředníky VII. a VIII. třídy. ${ }^{8}$ Nižší civilní státní zaměstnance pak jmenovaly hlavy jednotlivých zemí - místodržitelé a zemští prezidenti. ${ }^{9}$

Novou elitou říše tak podle tohoto schematu měli být primárně státní zaměstnanci v I. až IV. hodnostní třídě. Ve skutečnosti tomu tak ale úplně nebylo, a to hlavně ze dvou

4 „Ich bin lieber der erste Bürgerliche, als der letzte Adelige“ [cit. dle: Stögmüller 2010: 37]. Jeho dcery, které se provdaly do starobylých šlechtických rodin, Karoline sv. paní von Imhof (1859-1923) a Anna hraběnka von Lamberg (1861-1943), se s ohledem na své děti (aby se narodily šlechtickým rodičům) nechaly na základě otcových zásluh roku 1902 povýšit do šlechtického stavu. AVA, Adelsarchiv, Karoline und Anna geb. Werndl, Adelstand 1902. Též Granichstaedten-Czerva 1954: 104-106; Županič 2009: 699-710. Jediný Werndlův syn Josef Carl (1856-1883) zemřel mladý, ještě před otcem.

5 „... er wollte nicht als mehr erschienen als ein liberaler Burger“ [cit. dle: Engel-Janosi 1974: 17-18].

6 Aristokracie do svých řad osoby z nové šlechty prakticky nepřijímala. Jednou z mála výjimek byl Salomon Albert Anselm sv. pán Rothschild (1844-1911), který spolu s manželkou Bettinou Caroline de Rothschild (1858-1892) z pařížské linie získal 23. 12. 1887 jako vůbec první židovský šlechtic povolení přístupu ke dvoru. Toto privilegium mu vyjednal uherský ministerský předseda István hrabě Tisza za jeho zásluhy o snížení uherské zlaté renty z 6 na 4 procenta. Privilegium bylo 29. 1. 1906 rozšířeno na jeho děti [Neues Wiener Tagblatt (Tages-Ausgabe), 25. 12. 1887, 2; Weimarer historisch-genealoges Taschenbuch des gesamten Adels jehuäidischen Ursprungs 1912, 204]. Podobnou výsadu žádný jiný židovský rod v monarchii nezískal [Županič 2012: 584].

7 To také mohl být důvod, proč o šlechtický titul nepožádala celá řada ministrů, kterým by jinak bylo zcela jistě vyhověno. Šlechticem nebyl také jediný rakousko-uherský velvyslanec nearistokratického původu Konstantin Dumba (1856-1947) působící v USA (1913-1915) [srov. Konecny 1986: 1-3, 112-113].

8 Navíc jmenovali i subalterní úředníky, působící na ministerstvech a sluhy, kteří stáli mimo státní úřednictvo. K jmenování do̊stojníků: Wrede 1898: 63.

9 Megner 1985: 32-33. Dvanáctá hodnostní třída byla u státních úředníků a většiny druhů vojsk zrušena roku 1873. 
důvodů. Jeden představovala existence první společnosti rekrutované téměř výlučně z příslušníků aristokracie, do které tyto osoby neměly přístup, druhý nedostatečné platové ohodnocení rakouských státních zaměstnanců. Z tohoto úhlu pohledu měli lepší výchozí postavení podnikatelé, jejichž postavení ve společenské hierarchii monarchie se ale vymezovalo poměrně obtížně. Také proto někteří př́íslušníci mimořádně bohatých podnikatelských rodů i přes svou naprostou finanční nezávislost vstupovali do státní služby, protože jejich prestiž coby úředníků vysoce převyšovala prestiž byznysmenů [Sandgruber 2013: 124-126].

Podnikatelé samozřejmě (až na vzácné výjimky) mezi státní zaměstnance nepatřili a jejich místo ve společenské hierarchii proto bylo poměrně komplikované. Odraz této situace představovaly i jejich sňatky, protože osoby z řad podnikatelů a jejich rodin nacházely navzdory svému značnému (někdy dokonce mimořádnému) bohatství mezi členy starošlechtických rodin partnery jen velmi vzácně. Mnohem častější byly svazky s důstojníky nebo státními úředníky, u kterých byl nedostatek majetku kompenzován vysokou společenskou prestiží. Můžeme tak souhlasit s tezí Hartmuta Berghoffa [Berghoff 1994], podle kterého aristokratizace podnikatelů představovala spíše ojedinělý fenomén, mimo jiné právě díky zanedbatelnému podílu př́ibuzenských svazku s aristokracií. ${ }^{10}$

Na proces aristokratizace nemělo udílení šlechtických titulů žádný vliv, byt šlechtictví můžeme považovat za jeden z jeho průvodních znaků. Ve srovnání s Pruskem či Velkou Británií byla podunajská monarchie při nobilitacích velkorysejší a šlechtictvím zde byl oceněn i poměrně vysoký počet podnikatelů. Zapotřebí je ale zdůraznit jeden fakt. Šlechtický titul získaný před zánikem stavovské společnosti roku 1848 mohl být chápán jako vstupenka do exkluzivní společnosti, protože nositeli otevřel cestu k místu na zemském sněmu mezi šlechtickými stavy a tím nárok podílet se na politickém životě země. ${ }^{11}$ Přestože tato výsada nakonec zůstala řadě osob z titulárních či jiných ${ }^{12}$ důvodů odepřena, byly možnosti spojené se šlechtictvím $v$ předbřeznové éře mnohem větší.

Po roce 1848 neměla nobilitace v Rakousku s aristokratizací bezprostřední souvislost, protože šlechtictví již nebylo předpokladem příslušnosti k elitě. ${ }^{13}$ Dosavadní výsady šlechtických stavů byly téměř úplně odbourány a ty, které zůstaly, měly jen čestný charakter a neposkytovaly reálné výhody: právo na titul, predikát a erb, případně na určité čestné dvorské hodnosti. ${ }^{14}$ Protože tedy šlechtictví již reálné výhody nepřinášelo, bylo jeho přijetí

10 Tuto skutečnost velmi dobře na př́kladu rakouských podnikatelů doložili K. Megner a A. Fessen. Z jejich prací vyplývá, že žádná ze sledovaných podnikatelských rodin nedosáhla sňatkového propojení s aristokratickým rodem, nebo alespoň s rodem $\mathrm{z}$ řad staré šlechty. Z hlediska volby sňatkových partnerů tak podnikatelé stáli až za důstojníky a státními úředníky [Megner 1974: 295-301; Fessen 1974: 197-198].

11 V některých zemích monarchie (např̀ v českých zemích) bylo pro získání tohoto práva třeba dosáhnout rytíŕského titulu, jinde (např. v Uhrách) postačovalo prosté šlechtictví. Nezbytné ovšem bylo získání obyvatelského práva: v českých zemích tzv. inkolátu, v rakouských Landstandschaft, v Haliči a Uhrách indigenátu.

12 Diskriminováni byli hlavně židé, kteří bez ohledu na získaný titul nejen nemohli postoupit mezi stavy, ale také velmi dlouho (de facto do přijetí prosincové ústavy roku 1867) nemohli bez omezení nakupovat velkostatky a jiné nemovitosti. Přesto však jim nobilitace přinášela řadu výhod a mimořádné zvyšovala jejich společenskou prestiž [Gaugusch 2015; Županič - Fiala 2017: 65-75; Godsey 2017].

13 To ostatně již roku 2002 konstatoval M. Myška [Myška 2002]. Ke stejnému závěru dospěl již roku 1992 D. Schumann [Schumann 1992].

14 Ke šlechtickým výsadám v Rakousku podrobně: Mayrhofer - Pace 1901; Feigl 1991. Z dvorských titulů mohli novošlechtici získávat jen nejnižší, které nepředpokládaly původ od stanoveného počtu šlechtických předků čestnou hodnost stolníka (Truchsess) či palácové dámy (Palastdame). Jejich místo v dvorské hierarchii se ale nacházelo až na samotném konci [Županič 2006: 31-32]. 
otázkou jen osobní volby, nikoli předpokladem společenského vzestupu. ${ }^{15}$ Šlechtický titul se navíc během druhé poloviny 19. století s označení stavovské př́slušnosti transformoval ve specifickou formu státního vyznamenání, jehož prestiž byla odrazem tradice a faktu, že udělený titul byl vždy dědičný. ${ }^{16}$

Proměna šlechtictví coby symbolu př́slušnosti k urozené společnosti v čestný titul byla tím hlubší, že nejpozději od 60. let 19. století umožňoval udělený stupeň šlechtictví definovat společenské postavení jedince stejně, jako tomu bylo v př́padě rádu či vyznamenání. Toto pravidlo přitom bylo aplikováno na celou společnost monarchie, nikoli jen na státní zaměstnance. Názor, podle kterého je třeba chápat udílení titulů a řádů jako projev snahy o sociální byrokratizaci podnikatelstva je proto v zásadě správný [Popelka 2011: 115]. Jak ze získaných poznatků vyplývá, cílem bylo prostřednictvím konkrétního vyznamenání vymezit aktuální společenskou pozici jedince v tehdejší společnosti. Ovšem do chvíle, než bude zpracován reprezentativní vzorek podnikatelstva podunajské monarchie v dlouhém 19. století, nejsme bohužel schopni přesně říci, jak tyto kroky přijímali sami podnikatelé a jakou cenu pro ně rády a tituly měly. Zdá se však, že s výjimkou několika málo osobností, které odmítaly veškerá ocenění bez rozdílu, ${ }^{17}$ rády a čestné tituly přijímali všichni, a to včetně těch, kteři o šlechtický titul neměli zájem. ${ }^{18}$

Cílem této studie je zachycení vývoje a důvodů nobilitací podnikatelů v Rakouském císařství, a to v ére posledních dvou vladařů: Františka Josefa I. a Karla I. Na základě rozboru úředních materiálů státní, dvorské a panovnické provenience se pokusíme rekonstruovat vývoj šlechtické politiky vủči podnikatelstvu a obecněji též vymezit možností oceňování jejich zásluh po zániku stavovské společnosti roku 1848. Zaměříme se přitom především na postoj státu vůči těmto osobám, a především na otázku, kdo vůbec v úvahu pro povýšení do šlechtického stavu připadal a kdo nikoli. Stranou naopak budou ponechány osobní motivy zájmu či nezájmu o šlechtictví, které jsou vždy vysoce individuální a jen obtížně začlenitelné do širšího rámce.

Nobilitacemi rakouských podnikatelských elit se zabývala řada autorů, většina ovšem jen v širším kontextu, nebo s přihlédnutím k osudům významných osobností či jejich rodů [Arnbom 2002; Gaugusch 2011 a 2016; Záríický 2004; Popelka 2011; Kučera 2012: 81-90]. Výjimku představuje několik bohužel nepublikovaných diplomových a dizertačních prací

15 Individuální motivy, které jednotlivce vedly k zájmu o šlechtický titul, se hledají velmi obtížně, protože se na ústředních úřadech monarchie (ministerstva, panovníkova kabinetní kancelář) obvykle nedochovaly. Zde jsme odkázáni na materiály osobní povahy (rodinné archivy, korespondenci atd.), které u nové šlechty $\mathrm{v}$ úplnosti podchyceny nejsou a komparativní studie v tomto ohledu neexistují.

16 Dědičná nobilitace nebyla ve střední Evropě „dlouhého 19. stoleti“ pravidlem. Zejména jihoněmecká království, Bavorsko a Württembersko, jež byly na počátku 19. století značně ovlivněny napoleonskou Francií, udílely mnohem častěji osobní šlechtictví, než šlechtictví dědičné. Ad personam byly tituly udíleny také v Prusku, v podunajské monarchii však nikdy. Závěry na základě autorova výzkumu in: BayHStA, Adelsmatrikel a GStA, Heroldsamt; též Ernst 2001; Wunder 1981.

17 Takovou výjimkou byl např. velkoprůmyslník Karl Wittgestein (1847-1913).

18 Nositelem velkokř́íže Rádu Františka Josefa a komandérem Leopoldova řádu byl Arthur Krupp (1856-1938), jehož rezervovaný vztah k habsburskému rodu byl obecně znám a který neměl - stejně jako jeho strýc Alfred Krupp (1812-1887) - o šlechtický titul zájem. V Rakousku si však nechal potvrdit rodový erb, což vzhledem k tomu, že se zde nešlechtické erby se od roku 1820 neudílely, můžeme považovat za mimořádné vyznamenání [Göbl 1983-1985; Sandgruber 2013: 379-380]. 
vídeňské univerzity, jejichž záběr pokrývá téměř celé období existence Rakouského císařství. ${ }^{19} \mathrm{Z}$ nich se ale jen jediná, studie Karla Megnera, pokusila analyzovat vývoj rakouské nobilitační politiky, byt’ v poměrně krátkém období od přijetí dualismu (1867) do zrušení nobilitačních paragrafů většiny řádů rakousko-uherské monarchie (1884). Ostatní se primárně zaměřili na sociologickou stránku: původ podnikatelů, sňatkové strategie, počet dětí, výši majetku apod. Důvody, které vedly k udílení šlechtictví, podrobně nezkoumali a jen přebírali informace uvedené v diplomech či nobilitačních složkách uložených ve vídeňském šlechtickém archivu (Adelsarchiv). Takový přístup je ale mimořádně problematický, protože od konce 60. let nebyly důvody udělení šlechtictví, ve starších dokumentech označované jako „merita“, do diplomů zanášeny, a také ve starším období najdeme výrazné rozdíly mezi informacemi zapsanými do veřejných dokumentů (šlechtický diplom) a těch, které najdeme v interních spisech. ${ }^{20}$

Dosud bohužel neexistuje komplexní soupis všech rakouských nobilitací z let 1804 až 1918. Dnes nejvíce užívaný přehled Petera Frank-Döferinga [Frank-Döfering 1989] není bohužel zcela vyčerpávající, protože neeviduje velkou část nobilitací, při kterých nedošlo k vydání diplomu. Mnohem přesnější soupisy Arno Kerschbaumera se zatím omezují na léta první světové války [Kerschbaumer 2016 a 2017]. Značné limity má také dnes již klasická a hojně citovaná práce Hannse Jäger-Sunstenaua, jež upřesňuje a rozšiřuje starší studii Johanna Baptista Wittinga [Jäger-Sunstenau 1963; Witting 1898]. Poslední dvě práce ovšem nejsou seznamem udělených šlechtických titulů, ale statistickými studiemi, které se snaží o rozdělení nobilitovaných na základě jejich profesního zaměření. Zatímco Wittingova studie, vydaná při prŕležitosti půlstoletí vlády Františka Josefa, shrnuje nobilitace z let 1848 až 1898, Jäger-Sunstenauova práce se snaží zmapovat vývoj udílení šlechtických titulů od roku 1701 do zániku habsburské ř́íse na podzim 1918. Vzhledem k datu vydání je Wittingův článek logicky výlučně statistický. U Jäger-Sunstenaua ale podobný přístup překvapuje, stejně jako absence jakéhokoli historického úvodu, vytýčení metod a důvody vymezení jednotlivých sociálně-profesních skupin nobilitovaných. Jde však o jedinou komplexní práci na toto téma na přes uvedené nedostatky v zásadě nikoli chybnou. I když se autorovi nepodařilo podchytit všechna povýšení, můžeme konstatovat, že odchylky nejsou výrazné a dosahují ŕádu jednotek.

Starší Wittingova studie je ale v jednom ohledu lepší než Jäger-Sunstenauova: člení totiž př́ijemce titulů nejen podle profesí, ale také podle jejich postavení na žebřričku státní služby a též na základě způsobu povýšení. Řeší tedy otázku, zda k udělení titulu došlo na základě nejvyššího rozhodnutí, v důsledku udělení řádu (systematisierter Adel) nebo na základě vojenské služby (systemmäßiger Adel). Zatímco Wittingovi závěry se zdají být přesné v prrípadě státních zaměstnanců, u ostatních skupin obyvatelstva má jeho práce limity. Stejně jako Jäger-Sunstenau nevymezuje jednotlivé sociální skupiny, což při podrobnějším studiu působí problémy. ${ }^{21}$ Podle jeho přehledu tak mělo být v letech 1848-1898 do

19 S výjimkou let 1885-1909. Viz Komanovits 1974; Putz 1975; Megner 1974; Fessen 1974.

20 Spisy jsou uloženy v: AVA, Adelsarchiv. Část tohoto fondu byla po roce 1918 převezena do Československa, kde je uložena dodnes (in: NA, ŠA). Tyto materiály byly zpř́stupněny in Županič - Fiala - Koblasa 2014.

21 Podnikatelé (u Witting 1898 jsou uvedeny kategorie Industrielle, Großhändler, Banquiers, Fabrikanten, Kaufleute a Fabrikbesitzer) se mohou s největší pravděpodobností nacházet i v kategoriích Landesorgane, Deputierte, Gemeindeorgane a Private, ovšem vzhledem k absenci dalších informací ve studii nelze tuto hypotézu potvrdit. Do uvedeného počtu 236 nobilitací jsem naopak zahrnul i Wittingem vytvořenou kategorii Grosshändlers-Sohn a kategorii Handelskammerpräsident. 


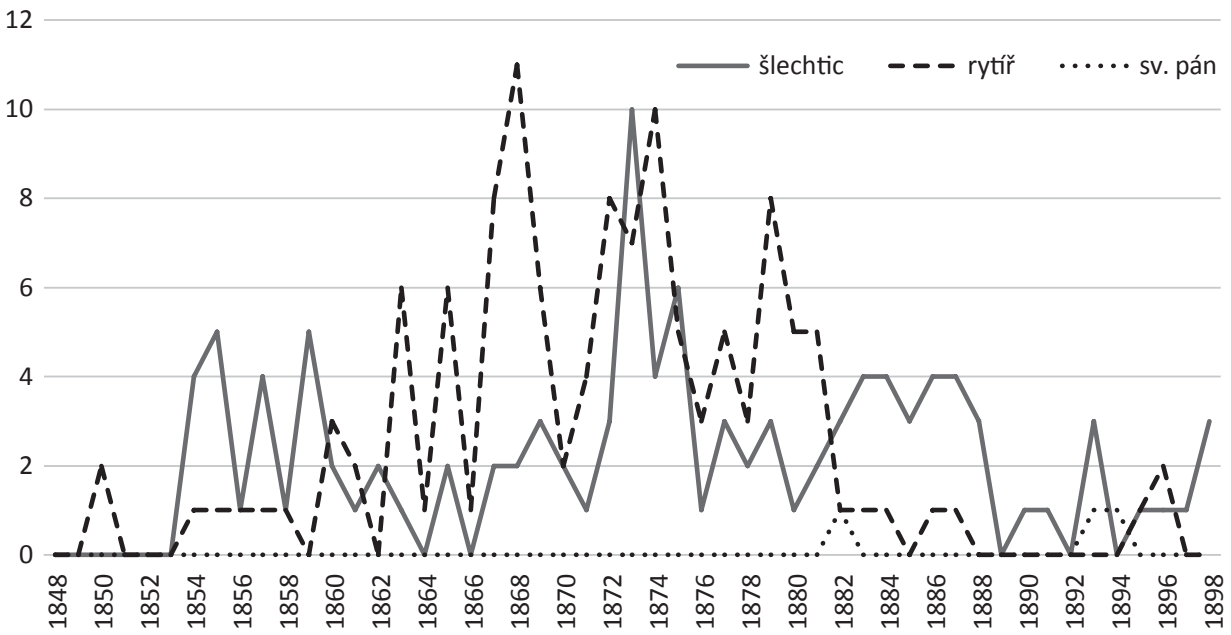

Graf 1: Nobilitace podnikatelů v Rakousku v letech 1848-1898 (dle J. B. Wittinga)

Zdroj: [Witting 1898]

šlechtického stavu povýšeno 236 podnikatelů, což je číslo mimořádně podhodnocené. Titulární a chronologické členění nobilitací je podle Wittinga následující (graf 1).

Mimořádně nízký počet povýšení mezi svobodné pány (tři osoby, všechny navíc povýšené nejvyšším rozhodnutím) uváděný Wittingem je také velmi podezřelý, protože je známo, že baronát byl udělen několika desítkám podnikatelů - v naprosté většině na základě Řádu železné koruny II. třídy.

Realitě proto odpovídají spíše údaje Jäger-Sunstenaua. Ten pro období let 1848 až 1918 uvádí celkem 829 nobilitovaných podnikatelů (obchodníků, průmyslníků a bankéřù), z toho 612 v období 1848 až 1898, což je počet je třikrát vyšší než u Wittinga. Vývoj a struktura udílení šlechtictví podle jeho studie proto vypadá velmi odlišně.

Jak Witting, tak Jäger-Sunstenau se však shodují v jedné věci: zásadním přelomem ve struktuře a počtu nobilitací (a to nejen podnikatelů) je rok 1884 a zrušení všech výsad spojených s udělením řádů monarchie [Gaugusch 2019]. Jak ale jasně vyplývá z grafu vycházejícího z Jäger-Sunstenauovy studie, byl pokles počtu udělených šlechtických titulů po roce 1884 dočasný a v polovině 90 . let došlo opět k výraznému nárůstu, byt počty povýšení nikdy nebyly tak vysoké, jako v předchozím období. Navíc se změnila struktura nobilitací. Zatímco od poloviny 60 . let u podnikatelů jednoznačně dominovalo povyšování do rytířského stavu (na základě udělení Řádu železné koruny III. třídy), po roce 1884 tito jedinci nejčastěji získávali prosté šlechtictví. Šlo o obdobný proces, jaký mưžeme sledovat ve stejném období u státních úředníků. ${ }^{22}$ Zajímavé je však je zachování podílu baronátů, který v obou časových úsecích překračoval 17 procent a po roce 1884 byl u podnikatelstva

22 Po zrušení nobilitačních paragrafů mohl na šlechtický titul dosáhnout až úředník v V. hodnostní třídě. Řád železné koruny III. třídy však byl udílen i úředníkům VI. hodnostní třídy [Županič 2019a, 492-494]. Viz též níže. 


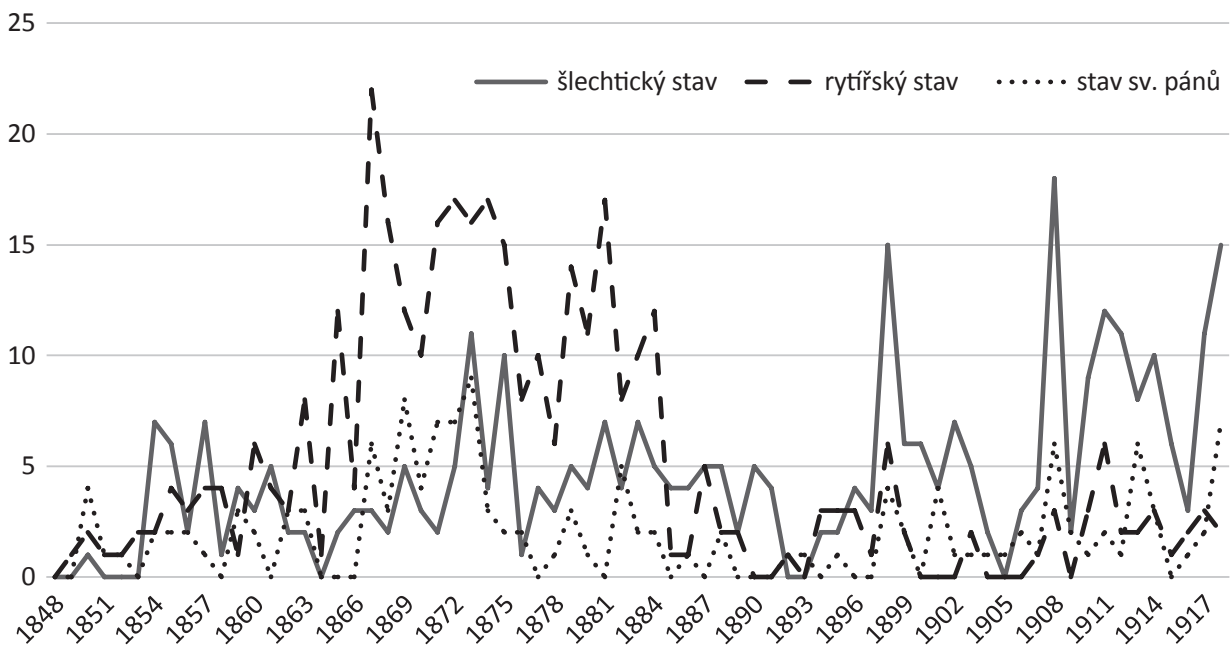

Graf 2: Nobilitace podnikatelů v Rakousku v letech 1848-1918 (dle H. Jäger-Sunstenau) Zdroj: [Jäger-Sunstenau 1963]

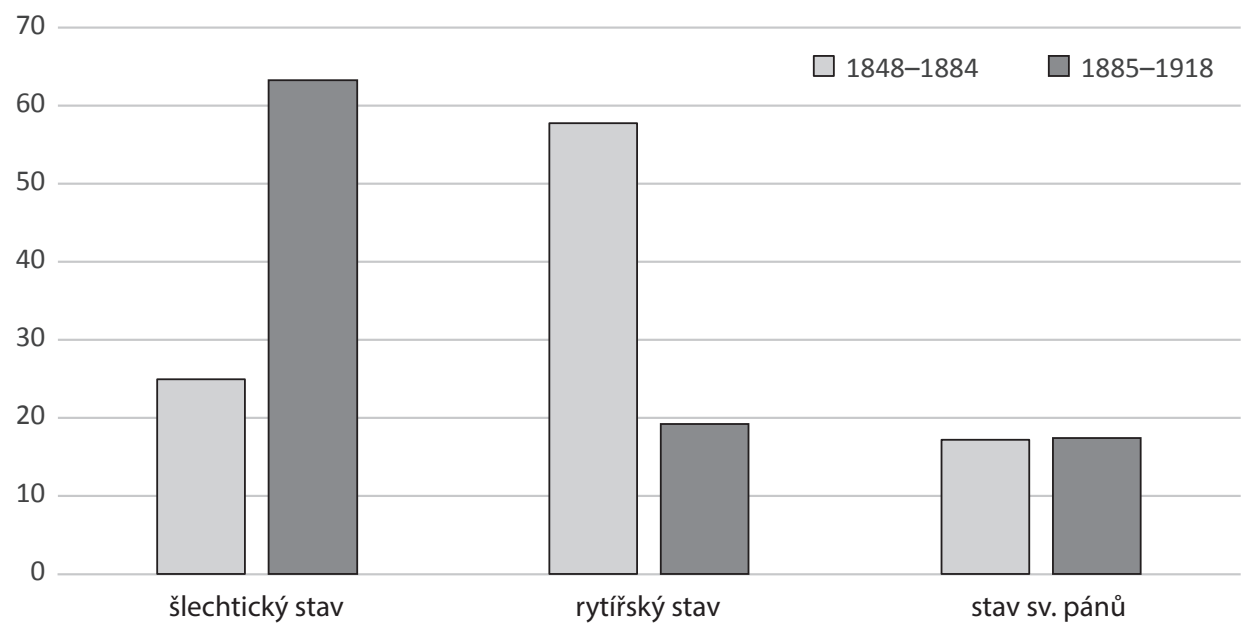

Graf 3: Procentuální rozdělení nobilitací podnikatelů podle uděleného stavu Zdroj: [Jäger-Sunstenau 1963]

dokonce vyšší, než u jiných sociálních skupin. Poměr povýšení mezi vyšší (stav svobodných pánů) a nižší (prosté šlechtictví, rytířský stav) šlechtu zůstal v obou obdobích stejný, zatímco u jiných sociálních skupin se zastoupení baronů snížilo [Gaugusch 2019; Županič 2019a: 493-498].

Snížení počtu nobilitaci podnikatelstvo jako celek ale zasáhlo výrazně. Zatímco v letech 1848-1884 jim byl některý stupeň šlechtictví udělen v 519 př́ípadech (průměrně 14krát za 


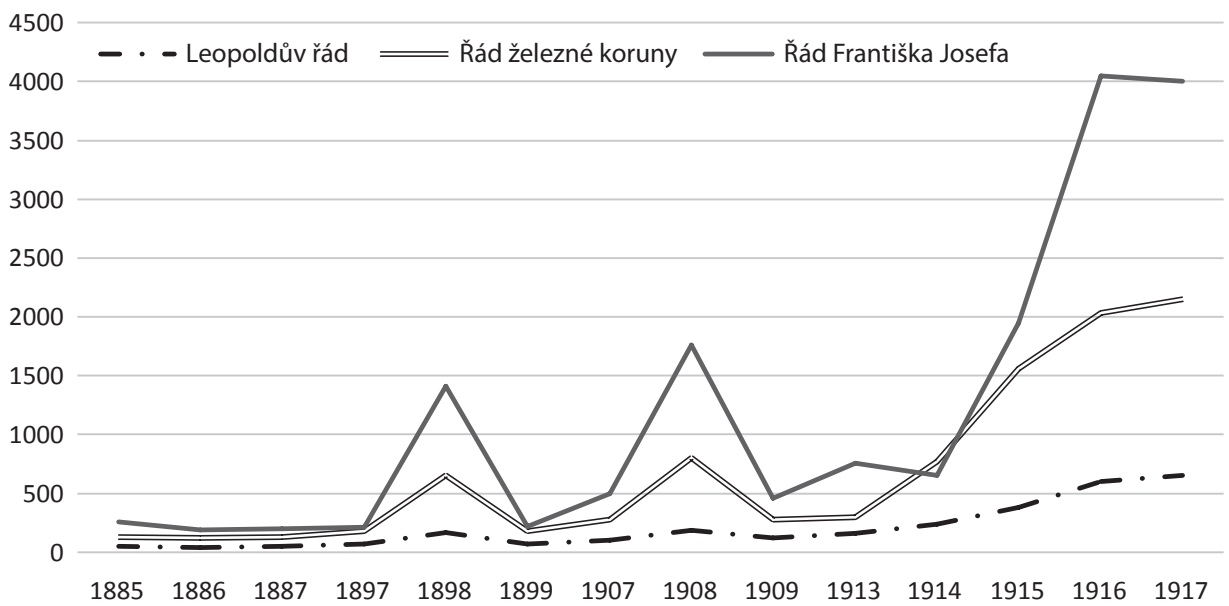

Graf 4: Orientační počty udílení řádů ve vybraných letech v období 1885-1917

Zdroj: [Pouzar 2006]

rok), po tomto datu šlo jen o 311 nobilitací, tedy cca o devět ročně. Pokles byl tím výraznější, že v Rakousku právě v této době došlo k výraznému zvýšení populace. ${ }^{23}$ Tato skutečnost (alespoň teoreticky) přispěla ke zvýšení hodnoty šlechtického titulu a na úkor dalších ocenění, zejména řádů, které byly naopak udíleny stále častěji. V průběhu času můžeme navíc vysledovat určité výkyvy, které sledovaly významné události v životě monarchie (jubilea, válečné konflikty atd.).

Častější udílení řádů a titulů se odrazilo i na sociálním profilu nově nobilitovaných osob (včetně podnikatelů). Zatímco do šedesátých let bylo naprosto výjimečné, aby tito lidé byli nějakým způsobem oceněni již dříve, od 80. let jde o běžný stav a na počátku 20. století byla nobilitace jedince, který již předtím nezískal řád či jiné vyznamenání, zcela výjimečná.

Ze závěrů zmíněných vysokoškolských studií z vídeňské univerzity a zejména $\mathrm{z}$ Wittingovy a Jäger-Sunstanauovy práce vychází dosud snad jediný český pokus o souhrnnou analýzu vývoje podnikatelské šlechty v dlouhém 19. století - krátká studie Milana Myšky [Myška 2002]. Ten se stejně jako výše uvedení autoři studentských prací opíral primárně o fondy šlechtického archivu a snažil se o vytvoření archetypu nobilitovaného podnikatele. Podle jeho názoru bylo k nabytí šlechtictví ve starší době, tedy od 18. do poloviny 19. století, nezbytné podporovat státní politiku, armádu a vyvíjet humanitární činnost, od druhé poloviny 19. století pak byly podle něj hlavním důvodem nobilitací těchto osob podnikatelské aktivity. Podle Myšky měla změna heterostereotypu podnikatele signalizovat zásadní proměnu společenských vrstev [Myška 2002].

23 Podle sčítání z roku 1880 žilo na území Předlitavska 22144244 obyvatel a o třicet let později již 28571934 [Die Ergebnisse der Volkszählung 1884: IV; Volkszählung 1917: 33]. 
Na základě nejnovějších poznatků je třeba tuto tezi odmítnout. Při výzkumu nobilitačních strategií podunajské monarchie v dlouhém 19. století nelze vycházet jen z nobilitačních složek (Adelsakten), jak činil, protože jejich informační hodnota postupem doby rychle klesá. Zatímco přibližně do poloviny 19. století je možné dohledat v těchto spisech opravdu takřka veškerou agendu spojenou s udělením titulu (žádost o nobilitaci, doporučení zemských vlád, vyjádření dvorské kanceláře, panovnické přípisky apod.), nejpozději od 60. let se tyto materiály ve spisech objevují stále méně. Od konce 19. století pak akta obsahují většinou již jen žádost o diplom, velmi stručný životopis, koncept listiny a úřední doklady (účty, protokoly o převzetí apod.) spojené s jejím zhotovením a předáním.

Objasnění důvodu této změny není za současného stavu poznání možné. Svou roli nepochybně sehrál rozvoj administrativy, neméně důležitý byl ale i přesun rozhodovacích pravomocí z panovníka na vládu. I po obnovení ústavnosti vladař sice udílel šlechtictví a řády podle vlastní vůle, $v$ podstatě stejné kompetence však získali i ministři, protože panovník jejich doporučení téměř nikdy nerozporoval. ${ }^{24}$ Zatímco se ale u panovníka jednalo osvrchované rozhodnutí jednotlivce, v případě vlády šlo o krok kolektivního orgánu: návrh na ocenění byl určitým ministrem přednesen na zasedání ministerské rady a v případě schválení předán panovníkově kabinetní kanceláři. Vladařův souhlas byl ale pro udělení vyznamenání či titulu nadále nezbytný. Po přijetí ústavy roku 1861 se tak vytvořil zajímavý model koexistence: císař udílel šlechtické tituly libovolným osobám podle svého rozhodnutí, přičemž nobilitační listiny kontrasignoval kompetentní ministr, ${ }^{25}$ a panovník víceméně bez výhrad akceptoval návrhy svých ministrů na udílení vyznamenání a titulů.

Díky tomuto postupu jsou ale poklady $\mathrm{k}$ udílení šlechtictví rozptýleny po několika archivech a fondech, což mimořádně komplikuje další výzkum. Zatímco spisy spojené s vydáváním diplomů jsou uloženy ve šlechtickém archivu (Adelsarchiv), definitivní verze memorand $\mathrm{k}$ udílení titulů se nachází $\mathrm{v}$ archivu císařovy kabinetní kanceláře (Kabinettsarchiv) uloženém v Haus-, Hof- und Staatsarchiv. Komparací s jinými dokumenty bylo navíc zjištěno, že i zde řada velmi důležitých informací chybí, přestože je jiné (níže zmíněné) zdroje obsahují. O důvodech tohoto stavu můžeme jen spekulovat. Jednou z příčin mohl být enormní nárůst agendy, kterou se panovník musel zabývat, druhou, pravděpodobnější, fakt, že postupem času vladař nobilitační politiku ovlivňoval stále méně a že o pozadí některých povýšení nemusel být vůbec informován.

Panovníkovi také nepředkládali návrhy na státní ocenění jen ministři. Stejná kompetence náležela i nejvyšším dvorním hodnostářům, kteří ovšem stáli mimo „klasický“ státní aparát a měli právo bez zprostředkování rakouské či uherské vlády vladaři navrhovat oceňování zasloužilých osob. V případě podnikatelů tak byly návrhy na udělení šlechtictví dohledány také v archivu úřadu nejvyššího hofmistra (Obersthofmeisteramt), ${ }^{26}$ do jehož kompetence spadaly i záležitosti dvorských muzeí, jež někteří podnikatelé sponzorovali. Další informace se nacházejí také v archivech kanceláří řádů monarchie, které (s výjimkou vojenského Ř́du Marie Terezie) též podléhaly úřadu nejvyššího hofmistra. ${ }^{27}$

24 K takovým situacím docházelo spíše za vlády Karla I. Z éry Františka Josefa podobný případ v archivních materiálech dosud zachycen nebyl [Županič 2011].

25 Šlechtické záležitosti v Rakousku podléhaly ministerstvu vnitra, resp. (1861-1867) státnímu ministerstvu.

26 HHStA, Obersthofmeisteramt, Akten-Hauptreihe.

27 HHStA, Obersthofmeisteramt, Orden der Eisernen Krone. 
Nejvíce návrhů na nobilitace a další vyznamenání přicházelo od druhé poloviny 19. století $\mathrm{z}$ vlády. Podklady $\mathrm{k}$ nim jsou uloženy ve spisech prezídia c. k. ministerstva vnitra (Ministerium des Innern, Präsidium, Akten), ${ }^{28}$ vzácněji pak v archivu prezídia ministerské rady (Ministerratspräsidium). ${ }^{29}$ Výpovědní hodnota těchto materiálů je zcela mimořádná. Ve spisech jsou totiž informace o interních jednáních, návrhy jednotlivých ministrů a často též doplňující materiály ve formě informací od místodržitelství či zemských vlád a policejních ředitelství. Bohužel archiv ministerstva vnitra byl roku 1927 vážně poškozen požárem Justičního paláce, při kterém byla jeho část zcela zničena, další vážně poškozena. Souvislá řada spisů se tak dochovala až od poloviny 90 . let 19. století, do této doby máme $\mathrm{k}$ dispozici pouze zlomky (tzv. pohořelé spisy/Brandakten).

$\mathrm{Z}$ důvodu komparace bylo nutné prostudovat také reprezentativní vzorek uherských nobilitací, jejichž počet po roce 1867 kontinuálně narůstal. Rozbor uherské šlechtické politiky sice není obsahem této práce, ovšem vzhledem $\mathrm{k}$ tomu, že někteří podnikatelé byli nejprve nobilitováni v jedné části říše a pak v druhé, je možné i zde dohledat důležité informace. ${ }^{30}$

Bylo již řečeno, že zánik stavovské společnosti přiměl stát k tomu, aby se pokusil populaci hierarchizovat podle jiného klíče. Jednu $\mathrm{z}$ variant představovalo členění podle voličských sborů v rámci kuriového volebního práva (po roce 1861), přesnější však bylo využití (výše zmíněného) systému hodnostních tř́d. Proto začali být (byt̉ virtuálně) na stupně tohoto žebřičku zařazováni i občané monarchie mimo státní službu. Hlavním faktorem dosažení určité pozice se přitom staly služby prokázané a prokazované státu a obecná prestiž spojená s výkonem určité funkce, nikoli původ a majetek. Systém byl do dokonalosti doveden během dlouhé vlády (1879-1893) ministerského předsedy hraběte Eduarda Taaffeho a zůstal v platnosti až do zániku monarchie. ${ }^{31}$ Udělené ocenění proto nebylo vázáno na míru zásluh, ale místo jedince na skutečném či virtuálním hodnostním žebříčku.

Viditelným symbolem př́slušnosti k elitě státu se tak stala držba šlechtického či jiného ${ }^{32}$ titulu a řádu, zatímco méně prestižní ocenění, zejména Záslužné kř̌iže byly určeny pro nižší složky populace. ${ }^{33}$ Zajímavé - a pro otázku šlechtictví osudové - bylo, že i po roce 1848 zůstal u řádů (s výjimkou nově zřízeného Řádu Františka Josefa) zachován tzv. nobilitační

28 AVA, Inneres, MdI, Präsidium. Zde se nachází několik desítek kartonů označených přímo Orden und Auszeichnungen (Kt. 1091-1187 a 2329-2448).

29 AVA, Ministerratspräsidium.

${ }^{30} M N L, K 20$. K uherské nobilitační politice např. Županič 2019a: 500-509.

31 Laich 1993: 62-63; Županič - Fiala 2017: 29-31. Protože podobný systém byl uplatňován i v Uhrách, je vysoce pravděpodobné, že k vytvoření níže uvedených norem došlo za součinnosti dvora (zástupců panovníka) a ve spolupráci s uherskou vládou.

32 Především tituly radů, které nebyly udíleny jen jako profesní úředníkům, ale též jako čestné zasloužilým osobám (c. k. rada, komerční rada atd.).

33 Záslužný kříž (Verdienstkreuz) byl zrrízen roku 1850 původně ve čtyřech, od roku 1916 v šesti třídách (zlatý, stř́ibrný a železný - bud’ s korunou, nebo bez koruny) jako náhrada za zrušené zlaté a stříbrné Záslužné medaile zvané Meritis. Byly udíleny osobám stojícím na nižších stupních společenského žebřičku. Výjimku představoval jen zlatý Záslužný kříž s korunou, který se stal nejnižším možným vyznamenáním pro konceptní úředníky VIII. a IX. hodnostní tř́́dy i osoby, jež si činily nárok na př́slušnost $\mathrm{k}$ druhé společnosti. Poměrně často byl udílen též významným podnikatelům, a to zejména na počátku jejich kariéry. 
paragraf, který umožňoval nositeli požádat o určitý šlechtický titul. Šlo o odkaz starší doby, kdy řád byl vnějším symbolem a titul reálným odrazem dosaženého společenského postavení. Tato výsada přetrvala až do roku $1884^{34}$ a díky liberalizaci poměrů a s tím spojeným nárůstem potenciálních př́ijemců řádů $\mathrm{z}$ neurozených vrstev, byla př́íčinou neobyčejného nárůstu nobilitací. ${ }^{35}$

Pomyslnou hranici pro udělení nejníže postaveného řádu s nobilitačním paragrafem, Železné koruny III. třídy, který umožňoval požádat o udělení rytířského titulu, představovala u úředníků VI. hodnostní třída. Vzácněji ale mohl být tento řád udělen i osobám na nižším stupni státní hierarchie, stejně jako prosté šlechtictvíi. ${ }^{36}$

Po zrušení řádového šlechtictví roku 1884 se situace kupodivu příliš nezměnila, jen s tím rozdílem, že nobilitace byla u úředníků obvykle podmíněna teprve dosažením $\mathrm{V}$. hodnostní třídy. Zachována zůstala i stratifikace nobilitací v rovině titulů, kdy byl udělený stav závislý na aktuální pozici jedince ve státní službě. Jedincům v V. tř́idě tak bylo udíleno prosté šlechtictví, ve IV. rytířský stav a výše postaveným baronát. Díky tomuto kroku se tak nobilitace po roce 1884 definitivně proměnila ve specifickou formu státního vyznamenání. $\mathrm{Na}$ důstojníky nebyl tento model aplikován, protože měli od roku 1757 nárok na povýšení do prostého šlechtického stavu po třiceti, respektive čtyřiceti letech služby. ${ }^{37}$

Komplikovaným problémem se ukázalo být oceňování osob, kteří nepatřili mezi státní zaměstnance - a to nejen tituly, ale také rády. Pokud totiž tito jedinci měli být za své zásluhy monarchii oceňováni, bylo nezbytné, aby udělené vyznamenání odpovídalo jejich společenské pozici. Jak již bylo řečeno, i v jejich př́padě se vzorem stal žebříček státní služby. Dosud není známo, že by k této otázce bylo vytvořeno zvláštní memorandum, praxe se však ustálila v přibližně této podobě (tabulka 1 ).

U osob stojících mimo státní službu byly možnosti ocenění výrazně menší než v případě státních zaměstnanců. Vysoce prestižní Řád sv. Štěpána byl totiž udílen jen zaměstnancům státu a dvora ve vysokých pozicích. Leopoldův řád získávaly osoby mimo státní službu udílen jen tehdy, pokud se aktivně angažovaly v politice a dosáhly významných pozic $\mathrm{v}$ říšské řadě či na zemských sněmech. ${ }^{38}$ Jen vzácně jím bývali dekorováni před-

34 Po tomto datu zůstal nárok na nobilitaci spojen jen s vojenským Řádem Marie Terezie, který se ale udílel jen vzácně [Županič 2017].

35 Mj. proto, že př́íslušníkům bojových jednotek nebyl až do první světové války udílen Řád Františka Josefa (pokládaný za výlučně civilní), a tak získávali řád bezprostředně vyšší Řád železné koruny [Županič 2015: 557; Županič 2019a: 491-492].

$36 \mathrm{~V}$ př́padě důstojníků platily při udílení řádů liberálnější předpisy a Řád železné koruny proto získávali i subalterní důstojníci v X.-VIII. třídě (major, hejtman, nadporučík). Úředníkům od VII. třídy níže byl naopak udílen jen velmi vzácně [Witting 1898; Županič 2006: 119-123].

37 Návrh na udílení rytířského titulu důstojníkům od IV. hodnostní tř́ídy byl zamítnut. Jak rytírský stav, tak baronát sice byl důstojníkům udílen, nikoli však na základě systému, ale jen ad hoc [Binder-Krieglstein 2000: 53-56; Županič 2019b: 131-134].

38 Zmínit můžeme Simona Wintesteina (1819-1883), původní profesí podnikatele a majitele spediční firmy. Roku 1862 se ale začal se intenzivně věnovat politice (od 1861 byl členem dolnorakouského zemského sněmu a poslanecké sněmovny říšské rady). Působil také na ředitelství několika železničních společností a roku 1865 se stal členem komise pro umoření státního dluhu. Roku 1867 získal rytířský kříž Leopoldova řádu (roku 1869 získal na jeho základě rytířský titul) a roku 1868 byl jmenován doživotním členem panské sněmovny. Roku 1874 byl povýšen do stavu sv. pánů a roku 1878 mu byl udělen komandérský křriž Leopoldova řádu. Winterstein nebyl zařazen do zkoumaného vzorku podnikatelů, protože přesné informace o pozadí jeho nobilitace a udělení ŕádu nejsou k dispozici [AVA, Inneres, MdI, Präsidium, Nr. 2163, Kt. 1137/1874]. 
Tabulka 1: Udílení řádů a vyznamenání osobám mimo státní službu

\begin{tabular}{|c|c|}
\hline $\begin{array}{l}\text { Hodnostní třída (u stát. } \\
\text { zaměstnanců) / tř́ída řádu } \\
\text { či vyznamenání }{ }^{39}\end{array}$ & Profesní kategorie vyznamenaných \\
\hline $\begin{array}{l}\text { III. / Řád železné koruny } \\
\text { I. trúdy }\end{array}$ & $\begin{array}{l}\text { Arcibiskupové a biskupové, majitelé a prezidenti } \\
\text { velkých bank }\end{array}$ \\
\hline $\begin{array}{l}\text { III. a IV. / Velkokříž } \\
\text { Řádu Františka Josefa }\end{array}$ & $\begin{array}{l}\text { Arcibiskupové a biskupové, členové rakouské panské } \\
\text { sněmovny (uherské sněmovny magnátů) }\end{array}$ \\
\hline $\begin{array}{l}\text { IV. / Řád železné koruny } \\
\text { II. třídy nebo Komturský kříž } \\
\text { Ŕádu Františka Josefa s hvězdou } \\
\text { (zal. 1869) }\end{array}$ & $\begin{array}{l}\text { Nejvýznamnější velkoprůmyslníci a bankéři, } \\
\text { vynikající vědci, umělci, architekti a stavitelé }\end{array}$ \\
\hline $\begin{array}{l}\text { V a VI. / Komturský kř́žz } \\
\text { Ŕádu Františka Josefa }\end{array}$ & $\begin{array}{l}\text { Církevní hodnostáři, vynikající vědci, významní advokáti, } \\
\text { notáři, stavitelé, velkoprůmyslníci a velkostatkáři }\end{array}$ \\
\hline $\begin{array}{l}\text { VI. / Řád železné koruny } \\
\text { III. tř́ídy }\end{array}$ & $\begin{array}{l}\text { Církevní hodnostáři, poslanci říšské rady, purkmistř̌i a jejich } \\
\text { zástupci, reprezentanti bank, průmyslu, pojištovnictví a želez- } \\
\text { ničních společností, advokáti a notáři, zástupci charitativních } \\
\text { institucí, přední lékaři, významní stavitelé a umělci }\end{array}$ \\
\hline $\begin{array}{l}\text { VII. / Rytířský křižž Řádu } \\
\text { Františka Josefa }\end{array}$ & $\begin{array}{l}\text { Děkani a jiní církevní hodnostáŕi, reprezentanti svobodných } \\
\text { profesí, významní podnikatelé (továrníci, velkoobchodníci) }\end{array}$ \\
\hline VIII. / zlatý $Z K+k$ & Majitelé továren a větších firem, významní živnostníci \\
\hline
\end{tabular}

Zdroj: vlastní výzkum

stavitelé nejvýznamnějších měst. ${ }^{40}$ Pro ostatní připadal v úvahu pouze Řád Františka Josefa a Řád železné koruny, který byl až do roku 1884 díky svému nobilitačnímu paragrafu vysoce ceněný. Přímé nobilitace panovnickým rozhodnutím byly vždy oceněním zcela mimořádným, a to zejména po zrušení nobilitačních paragrafů.

Dohledání informaci o pozadí a důvodech nobilitací podnikatelů představuje poměrně obtížný úkol. Nejde jen o rozsah př́slušné materie a roztřištěnost do řady fondů, ale především o ztrátu pramenů zásadní hodnoty při požáru roku 1927. K tomu navíc přistupuje fakt, že rekonstruovat je možné pouze ty z nobilitací, které nevycházely z vlastního rozhodnutí panovníka. K jeho výnosům v podobě osobního či kabinetního listu (Allerhöchtes Handschreiben resp. Kabinettschreiben) totiž žádné pomocné materiály nebyly zpracovávány, protože je vladař nepotřeboval. Listy jen dával ministrovi vnitra na vědomí své rozhodnutí a pověřil jej vyřízením úředních formalit. Podobně komplikovaná se ukázala být otázka udílení státních vyznamenání při př́ležitosti panovnických jubileí a narozenin

39 Toto rozdělení není fixní, ale vyplývá z vlastního autorova výzkumu. Římská číslice odkazuje na hodnostní třídu státní služby u státních zaměstnanců, kteří vyznamenání tohoto stupně obvykle získávali. Zkratka zlatý ZK+k označuje zlatý Záslužný kříž s korunou.

40 Např. za zásluhy během války roku 1866 pražský primátor JUDr. Václav Bělský (1818-1878) rytířský kříž Leopoldova řádu a o rok později na jeho základě rytíŕský titul [AVA, Inneres, MdI, Präsidium, Kt. 1120/1866]. 
v letech 1898, 1908 a 1910. I pokud máme k dispozici soupisy oceněných (což není zcela běžné, častěji ve spisech nacházíme jen čísla), důvody chybějí. ${ }^{41}$

Přesto se po několikaletém výzkumu se podařilo rekonstruovat pozadí celkem 216 udělení šlechtictví 200 podnikatelům, ze kterých byli někteří nobilitováni opakovaně. ${ }^{42}$ Tento počet můžeme považovat za skutečně reprezentativní vzorek - jde totiž o plnou čtvrtinu Jäger-Sunstenauem evidovaných povýšení. Nobilitováni byli téměř výlučně muži, k povýšení žen došlo jen ve dvou př́padech: Claary Waagnerové (1787-1877) a Anny von Liebig (1855-1926), které jsou i při celorakouském srovnání zcela mimořádné [Županič 2009: 706-710]. Bohužel se nepodařilo rozložit celek nobilitovaného podnikatelstva zcela rovnoměrně, protože míra dochování úředních materiálů není v každé dekádě stejná. S výjimkou let $1849^{43}$ až 1859 se ale podařilo dodržet minimum deseti nobilitačních řízení. ${ }^{44}$ Toto číslo je ve většině dalších časových úseků překročeno, nejvýrazněji pak v 70. letech, kdy bylo jen za zásluhy o úspěch Světové výstavy ve Vídni roku 1873 nobilitováno 17 podnikatelů. ${ }^{45}$

Mezi podnikatelstvo nebyli zařazeni jen průmyslníci a bankéři, ale také neurození či nobilitovaní velkostatkáři, kteří se zabývali podnikáním v potravinářském průmyslu, a vysocí činitelé (hlavně ředitelé) bank a pojištoven. Vzhledem k tomu, že mezi významnými rakouskými podnikateli najdeme i občany jiných států, byli i oni zahrnutí do tohoto celku, pokud ovšem trvale žili na území monarchie. ${ }^{46}$

Při rekonstrukci důvodu nobilitací bylo zjištěno, že většině osob nebyl šlechtický titul udělen $\mathrm{z}$ jednoho konkrétního důvodu a pokud ano, pak častěji ve starší době, než v posledních dekádách existence monarchie. ${ }^{47}$ Obvyklejší byla kumulace zásluh s tím, že obvykle jedna byla vyzdvižena jako dominantní a další měly doplňující charakter. ${ }^{48}$ Analý-

41 HHStA, KK, 4184/1898; tamtéž, 3634/1908; tamtéž, 2573/1910. Jde jen o tabulky shrnující počet jednotlivých udělených vyznamenání. Jmenný soupis, často s uvedením nominující osoby, ovšem bez udání důvodu byl dohledán jen k roku 1908 [AVA, Inneres, MdI, Präsidium, Kt 2385/1908]. Ale i tak se z celkem čtyř nobilitací podnikatelů, které jsou v této složce zmíněny, podařilo dohledat pozadí jediné: brněnského velkoprůmyslníka Adolfa Kürschnera (1844-1915), a to jen díky tomu, že mu byl roku 1911 udělen i uherský baronát [AVA, Adelsarchiv, Adolf Kürschner, Adelsakt (1908-1911)]. Nobilitací podnikatelů při prŕležitosti jubilea roku 1908 ale bylo více, ovšem informace o jejich pozadí postrádáme.

42 V některých př́padech se bohužel nepodařilo důvody dalších nobilitací dohledat. Kokrétně jde zejména o baronáty udělené při př́íležitosti panovnického jubilea roku 1908 Georgu Haasovi šl. von Hasenfels (1841-1914) a bratrům Oscaru (1844-1927) a Ottomaru šl. von Klinger (1852-1918).

43 Vzhledem k tomu, že František Josef I. nastoupil na trůn až 2. 12. 1848, neuskutečnil roku 1848 žádnou nobilitaci [Witting 1898].

44 Rozvržení jednotlivých nobilitačních řízení je následující: 1849-1859: 7, 1860-1869: 33, 1870-1879: 76, 18801889: 20, 1890-1899: 10, 1900-1909: 25, 1910-1918: 45.

$45 \mathrm{Z}$ tohoto počtu čtyři získali baronát, osm rytírský titul a 5 šlechtický stav [HHStA, KK, 4025/1873, též Županič 2008: 261-286].

$46 \mathrm{Z}$ tohoto důvodu jsou v tomto soupise rakouských nobilitací též někteří uherští podnikatelé (Schey, Popper, Kürschner), kterým ale byl z nejrůznějších důvodů udělen rakouský titul (obvykle žili v Předlitavsku či dokonce ve Vídni). Pokud byli do tohoto soupisu zařazeni jiní cizinci (nikoli Uhři), pak bylo nezbytné, aby byli s monarchií provázáni hospodářsky, případně aby později získali zdejší občanství (např. bankéř Ignaz Ephrussi, původem z Ruska, či ředitel pojištovacího ústavu Riunione adriatica di sicurtá v Terstu Alexander Daninos, který měl francouzské občanství).

47 Např. Kaliman Minerbi získal roku 1849 Řád železné koruny III. třídy (1850 rytířský stav) za zásluhy o rozvoj terstské burzy. Leopold šlechtic von Lämel byl roku 1856 vyznamenán týmž řádem (1856 rytířský stav) za zásluhy o zřízení banky o zřízení Creditanstalt. Železnou korunu III. tř́ídy obdržel roku 1868 také Aron Pollak (1869 rytířský stav), a to při příležitosti dokončení Rudolfina, domu pro 75 nemajetných studentů vídeňské techniky, jehož výstavbu financoval.

48 Např. bankéři Ignazi Ephrussimu (1829-1899) byl Řád železné koruny III. tř́idy roku 1871 (a následně rytířský stav), že vytvořil z vídeňských bankovních domů Ignatz Ephrussi \& Comp., Paul Schiff a Max Kann \& Comp. 
zou archivních dokumentů se postupně podařilo vymezit několik kategorií hlavních zásluh uváděných cobydůvod nobilitací:

- Bankovní a finanční služby státu (participace na státních půjčkách, snížení úrokových sazeb atd.).

- Humanitární zásluhy (včetně finančních darů).

- Podpora vládní politiky (včetně podpory vlády v tisku).

- Aktivní působení v politice (zejména na státní, ale též na regionální úrovni).

- Zásluhy o rozvoj hospodářství (budování a provoz továren, bank a železnic, rozvoj zemědělství a obchodu).

- Dary uměleckých a př́rodovědných sbírek.

- Podpora rakouských zájmů v zahraničí (zásluhy o posílení exportu a hospodářsko-politická „expanze“).

Za specifické kategorie můžeme označit dvě:

- Reprezentace monarchie na světových výstavách (vzácněji regionálních zemských výstavách), se kterou se (jako s důvodem nobilitace) můžeme setkat od 60. do 80 . let s těžištěm ve vídeňské výstavě roku 1873.

- Zahraničně-politické důvody, kdy k nobilitaci podnikatele došlo na výslovnou žádost zahraničního suveréna. ${ }^{49}$

Podle těchto kategorií vypadaly důvody nobilitací v čase následovně (tabulka 2).50

O rostoucím významu „humanitárních zásluh", obvykle finančních darů na dobročinné či veřejně prospěšné účely, svědčí pak graf 5 . Ten - opět percentuálně - zachycuje klesající význam zásluh o rozvoj hospodářství, oceňovaných zejména v první polovině 19. století ve srovnání se zásluhami humanitárními.

Z grafu 5 jasně vyplývá, že hlavní důvody pro udělení šlechtictví byly v zásadě dva: zásluhy o rozvoj hospodářství, jejichž váha ale od počátku 70. let klesala, a humanitární aktivity. Graf také vyvrací názor některých autorů, podle kterých byla u podnikatelů stále více oceňována jejich hospodářská činnost, zatímco zásluhy na sociálním poli (péče o dělnictvo a nemajetné, mecenát atd.) hrály od poloviny 19 . století jen doplňující úlohu. Mělo jít o zásadní rozdíl oproti situaci v době osvícenství a v první polovině 19. století, kdy byly při nobilitacích těchto osob společně vyzdvihovány zásluhy ekonomické i obecně prospěšné [Myška 2002].

a pařížských bank Samuel Haber a Anton Schnapper konzorcium, které zajistilo Komisi pro regulaci Dunaje (Donau-Regulierungs-Komission) půjčku s mimořádně výhodnou úrokovou sazbou ve výši 2,3 \% (obvyklá byla 4 \%). Kromě toho měl velké zásluhy o oživení rakouského obchodu do Oděsy a poskytl opakovaně velkorysými dary vídeňským chudým [AVA, Inneres, MdI Präsidium, Kt. 1130-1131].

49 Zmínit můžeme Mosese, rytíře von Waldberg (1832-1901), bankéře původem z rumuského Iași a později rakouského občana, kterému byl na přímou žádost srbského krále Milana roku 1884 udělen Řád železné koruny II. třídy (a na jeho základě baronát). Waldberg z Milanova pověření výhodně prodal v Rusku ležící statky jeho manželky Natálie [HHStA, KK, 316/1884]. Řád železné koruny II. třídy (a následně rytířský stav) byl roku 1869 též udělen alexandrijskému bankéři Heinrichu Schwabacherovi (1823-?), důvěrníkovi egyptského chedíva Ismaila, který dal Rakousku najevo, že by uvítal jeho vyznamenání [HHStA, KK, 2319/1869]. V př́ípadě dalšího egyptského finančníka Jacoba Levyho Menasceho (1809-1882), osobního bankéře chedíva Ismaila, došlo k udělení (1873) Ř́du železné koruny III. třídy a rytířského stavu na přímou žádost tureckého ministra zahraničí Mehmeda Rašída Paši [HHStA, KK, 3104/1873].

50 Příčiny nobilitací nejsou z důvodu nestejného počtu povýšení v jednotlivých dekádách posuzovány, uvedeny v absolutních číslech, ale v procentech. Graf byl vytvořen na základě vlastního výzkumu v Österreichisches Staatsarchiv. 
Tabulka 2: Důvody nobilitací podnikatelů v letech 1850-1918 (v procentech)

\begin{tabular}{|c|c|c|c|c|c|c|c|}
\hline & $\begin{array}{l}0 \\
10 \\
\infty \\
1 \\
0 \\
\infty \\
\infty \\
-1\end{array}$ & $\begin{array}{l}\text { aे } \\
0 \\
1 \\
0 \\
0 \\
0\end{array}$ & 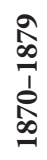 & $\begin{array}{l}\infty \\
\infty \\
\infty \\
1 \\
\infty \\
\infty \\
\infty\end{array}$ & $\begin{array}{l}\text { ळे } \\
\text { 1 } \\
\text { ஓे } \\
\infty\end{array}$ & $\begin{array}{l}\text { ڤे } \\
\frac{1}{1} \\
\text { ஓे }\end{array}$ & $\begin{array}{l}\frac{\infty}{\sigma} \\
\frac{1}{2} \\
\frac{1}{2}\end{array}$ \\
\hline Bankovní a finanční služby státu & 11 & 25 & 9 & 4 & 5 & 7 & 11 \\
\hline Dary uměleckých a/či přírodovědných sbírek & - & - & - & 4 & 16 & 5 & 5 \\
\hline Diplomatické (zahraničně-politické) důvody & - & - & - & 4 & - & - & - \\
\hline Humanitární zásluhy & 22 & 33 & 23 & 46 & 32 & 55 & 51 \\
\hline Podpora rakouských zájmů v zahraničí & - & 7 & 5 & 4 & 5 & - & 5 \\
\hline Politická podpora vlády & 22 & 17 & 9 & 9 & 21 & 15 & 8 \\
\hline $\begin{array}{l}\text { Reprezentace monarchie na Světových } \\
\text { výstavách }\end{array}$ & - & 3 & 26 & 4 & - & - & - \\
\hline Reprezentace monarchie na Zemské výstavě & - & - & - & 4 & - & - & - \\
\hline Zásluhy o rozvoj hospodářství & 45 & 15 & 28 & 21 & 21 & 18 & 2 \\
\hline
\end{tabular}

Zdroj: vlastní výzkum

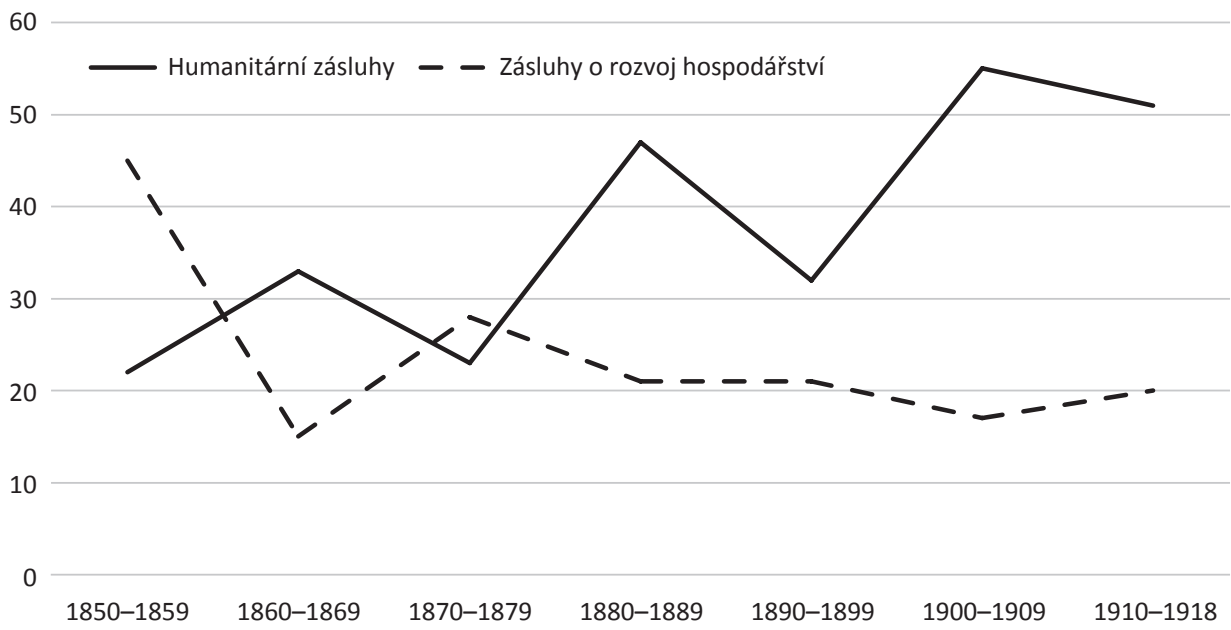

Graf 5: Podíl zásluh o rozvoj hospodářství a zásluh humanitárních na udílení šlechtictví podnikatelům

Zdroj: vlastní výzkum

Na základě rozboru archivních dokumentů musíme tuto tezi odmítnout. Samotné podnikatelské aktivity totiž mohly být důvodem nobilitací podnikatelů jen výjimečně, protože v jejich př́padě bylo naprosto nezbytné vylepšit svůj společenský profil zásluhami i v jiné oblasti. Důvod byl logický. Na rozdíl od vojáků a úředníků, kteří pracovali výlučně pro stát, bylo podle obecně přijímaného názoru náplní činnosti podnikatelů generování zisku. 
Stát sice jejich zásluhy o rozvoj ekonomiky uznával, ale to k udělení vyznamenání většinou nestačilo. Proto bylo nezbytné vykázat se i jinými zásluhami.

Největší prestiž samozřejmě nabízela činnost v oblasti politiky, která ovšem musela být dlouhodobá a $\mathrm{z}$ tohoto důvodu také časově velmi náročná. ${ }^{51}$ Podpora vládní politiky ale nemusela být realizována jen z poslaneckých lavic, protože řády a tituly získávali za svůj vstřícný postoj k vládní politice například i tiskoví magnáti. ${ }^{52}$ Velmi oceňována byla i reprezentace monarchie na Světových výstavách, kde podnikatelé nejen zasedali v nejrůznějších výborech a komisích, ale mnohdy také celou akci spolufinancovali. V tomto ohledu je třeba zdůraznit zejména mimořádně vysoký počet ocenění spojených s uspořádáním Světové výstavy ve Vídni roku 1873, kde mezi oceněnými podnikateli nacházíme takové osobnosti, jakou byl např. slavný majitel tužkařské továrny Koh-i-Noor Karl Hardtmuth (1804-1881). ${ }^{53}$

Další možnost představovala pomoc státu v oblastech, které s podnikatelskými aktivitami souvisely, ale jejich výnos (at již finanční či jiný) plynul ve prospěch monarchie. Šlo o účast v nejrůznějších odborných výborech či komisích, jež připravovaly nové zákony, a participaci na mezinárodních jednáních. ${ }^{54}$ Velmi ceněny byly zásluhy o rozšírené železniční sítě a jejich převod od soukromých společností do rukou státu, ${ }^{55}$ ale také zásluhy o snížení státního dluhu, zajištění zahraničních půjček nebo snížení jejich úrokových sazeb, př́padně emise státních dluhopisů na zahraničních trzích. ${ }^{56}$ Za první světové války

51 Srov. povýšení velkoprůmyslníka Adalberta Kulpa (1850-1932) do šlechtického stavu za zásluhy, které prokázal jako poslanec moravského zemského sněmu a říšské rady, a za podíl na uzavření tzv. moravského vyrovnání roku 1905 [HHStA, KK, 470/1914]. Velkostatkář a bankéř Franz von Hopfen (1825-1901), který za svou podporu vlády v říšské radě během jednání let 1861-1862 získal Řád železné koruny III. třídy (1863) a následně rytířský titul, se z podnikání kvưli politice nakonec zcela stáhl. V řŕšské radě se později stal předsedou Poslanecké sněmovny a byl (1872) vyznamenán komandérským křížem Leopoldova řádu (1873 na jeho základě získal baronát), který byl jinak podnikatelům nedostupný. Zajímavý př́ípad představoval Ludwig Oppenheimer (1843-1909), jenž se jako poslanec českého zemského sněmu zasloužil o zvolení říšského kancléře Beusta do liberecké obchodní komory, následně do českého zemského sněmu a poslanecké sněmovny říšské rady, za což byl roku 1867 oceněn Rádem železné koruny III. třídy (1868 rytíř). Stav sv. pánů mu byl udělen (1878) za podíl na jednání o hospodářském vyrovnání s Uhrami [HHStA, KK, 4722/1867; tamtéž, 3534/1878].

52 Řádem železné koruny III. tř́ídy byl (1867) vyznamenán majitel listu Fremdenblatt Gustav Heine (1810-1886), od roku 1867 rytír, kterému byl roku 1870 ze stejných důvodů udělen i baronát [AVA, Inneres, MdI, Präsidium, Nr. 4628/1870, Kt. 1129]. Řád železné koruny III. třídy a rytířský stav získal (1869) i Gustav Schlesinger (1833-1906), majitel novin Pester Lloyd [HHStA, KK, 1342/1869].

53 Hardtmuth byl za zásluhy o úspěch výstavy povýšen do šlechtického stavu [HHStA, KK, 4025/1873].

54 Velkoobchodník a agent bankovního domu Rothschild Horaz Landau (1824-1903) získal za zásluhy při jednání o podrobnostech mírové smlouvy s Itálií roku 1866 Rád železné koruny III. třídy (1867 rytířský stav), protože se mu podařilo přispět ke zvýšení odškodnění přiznaného Rakousku na 35 milionů zlatých [HHStA, KK, 3637/1866 - ve složce je omylem uveden s křestním jménem Moritz; AVA, Adelsarchiv, Horaz Landau, Ritterstand 1867].

55 Za zásluhy o budování železnic získal šlechtický titul (1877) Moritz Frölich (1827-1896), podnikatel a majitel realit [HHStA, KK, 3421/1877].

56 Bankéři Ignazi Ephrussimu (1829-1899) byl Řád železné koruny III. tř́idy a následně rytířský stav (1871) udělen mj. za o vývoz rakouských státních dluhopisů do zahraničí (viz též výše). Ředitel banky Creditanstalt Gustav Mauthner (1848-1902) získal roku 1884 stejný řád (a rytířský titul) za zásluhy o umoření většiny dluhopisů s úrokovou sazbou 4 \% zlaté renty z roku 1880 [HHStA, KK, 1590/1884. AVA, Inneres, MdI Präsidium, Kt. 1130 a 1131]. Velkostatkář a továrník Ludwig von Haber (1804-1892) byl roku 1869 povýšen do stavu sv. pánů za spolufinancování a zajištění půjček pro řadu železničních staveb v Rakousko-Uhersku a umístění rakouské státní půjčky na francouzském trhu [AVA, Inneres, MdI Präsidium, Kt. 1126/1869]. 
byly takto (podobně jako za válek napoleonských) odměňovány zásluhy o uzavření válečných půjček. ${ }^{57}$

Jak z grafu ovšem jednoznačně vyplývá, většina podnikatelů získávala od poloviny 19. století šlechtický titul na základě finančních či věcných darů na dobročinné a obecně prospěšné účely. Díky tomu mohlo udělení šlechtictví připomínat vzájemně výhodný obchod, kdy jedinec de facto vyměnil podnikáním vydělané peníze za titul, jenž zvýšil jeho společenskou prestiž. Jak dokládají archivní materiály, šlo obvykle o interní (a veřejnosti neznámou) dohodu mezi podnikatelem a rakouskou vládou, př́padně vysokým úředníkem císařského dvora. Nobilitace byla někdy důsledkem jednorázového daru vyšší hodnoty, obvykleji však důsledkem dlouhodobých aktivit tohoto druhu. $\mathrm{Z}$ archivních materiálů jasně vyplývá, že někteří podnikatelé dokonce postupně navyšovali výši svých darů $s$ cílem dosáhnout určité hranice, po které by mohli požádat o šlechtický titul. ${ }^{58}$ Pokud ale byla podnikatelova dobročinnost státem oceněna jinou formou než šlechtictvím (např. řádem), bylo zapotřebí prokázat další zásluhy (vydat další finance), protože jeden a tentýž čin nemohl být oceněn dvakrát. ${ }^{59}$ Nejobvyklejším důvodem nobilitace proto bylo kumulování několika druhů zásluh: například spojení rozvoje průmyslu a darů na dobročinnost. Konkrétní částky, které byly důvodem udělení titulů, se podařilo zjistit v 51 př́padech z celkových 216 nobilitací, a to jen v období let 1859 až 1918, přičemž více než 60 procent (31 osob) z tohoto počtu připadá na období po roce 1900 . O některých dalších podnikatelích víme, že titul získali za finanční dary, ale jejich výše zůstává neznámá. ${ }^{60}$

57 Srov. udělení šlechtického titulu prezidentu Union Bank Eugenu Minkusovi (1841-1923) a řediteli Wiener Bankverein Bernhardu Popperovi (1853-1931) [HHStA, KK, 935/1915; Županič 2012, 484 a 545].

58 Zcela jednoznačně je tento proces zdokumentován u Rudolfa Hoscheka (1855 - po 1932). Ten roku 1894 dosáhl obnovení českého rytî́rského stavu s predikátem „von Mühlheim“, který mu byl ovšem roku 1905 odňat, protože agent, který pro něj žádost o renobilitaci zpracovával, si za tímto účelem vyrobil falza. Po neúspěšném pokusu získat titul prostřednictvím adopce daroval v letech 1905-1908 - zčásti sám, zčásti s bratrem Gustavem (1847-1907) - nejméně $122500 \mathrm{~K}$ na dobročinné a veřejně prospěšné účely a roku 1908 mu byl udělen šlechtický titul [HHStA, KK, 2250/1908; NA, ŠA, kt. 32-33; Županič - Fiala - Koblasa 2014: 155-157]. Podrobnou evidenci svých darů ve výši 62332 zl. vyč́slil ve své žádosti o nobilitaci Karl August Christian Schik (1836-1901), roku 1881 povýšený do šlechtického stavu [AVA, Inneres, MdI Präsidium, Kt. 1145/1881]. Velmi zajímavá je v tomto ohledu žádost vdovy po Ludwigu rytíri von Liebig Anny (1855-1926), která usilovala o to, aby získala stav sv. pánů, jímž disponovala druhá linie rodu Liebigů. Ve své žádosti uvedla, že na dobročinnost věnovala během let celkem $92673,70 \mathrm{~K}$. K a přiložila podrobný soupis všech donací od částek přesahujících $20000 \mathrm{~K}$ po pouhé $2 \mathrm{~K}$ [AVA, Adelsarchiv, Anna von Liebig, Freiherrnstand 1916/17; Fessen 1974: 225-234].

59 Hermann Kuffner (1822-1905), který získal šlechtický titul (1900) za poskytnutí pozemku v hodnotě 40000 K a dar $100000 \mathrm{~K}$ na výstavbu nové budovy okresního soudu v Břeclavi, získal již roku 1881 rytiŕský kř́iž Řádu Františka Josefa za zřízení nadace pro vdovy a sirotky po důstojnících ve výši 30000 zl. Nobilitace byla oceněním darů ve výši 58000 zl. na zř́zení nemocnice v Břeclavi (1888), 10000 zl. (1889) nadaci pro práce neschopné drobné živnostníky a dalších částek na dobročinnost [AVA, Inneres, MdI Präsidium, Kt. 2332/1900; HHStA, KK, 2132/1900]. Velkoprůmyslník Emil rytír von Kubinzky (1843-1907) roku 1898 zř́́dil nadaci k podpoře nemohoucích dělníkủ ve výši $200000 \mathrm{~K}$, za což byl vyznamenán Rádem železné koruny III. třídy. Kromě toho prokázal mimořádné zásluhy při rozvoji průmyslu a zahraničního obchodu (mj. z funkce vicekonzula USA v monarchii) a byl též členem a funkcionářem řady odborných grémií. Za tyto zásluhy získal roku 1901 baronát [HHStA, KK, 2711/1901]. Textilní podnikatel Josef Bartoň (1838-1920) daroval při př́ležitosti 60. panovnického jubilea (1908), 150000 K na zř́zzení sirotčince v Náchodě, za což mu byl udělen rytî́rský kříž Řádu Františka Josefa. Když byl o čtyři roky později (1912) povýšen do rytírského stavu, byla v odůvodnění nobilitace vyzdvižena také jeho péče o zaměstnance, činnost ve funkci starosty města Náchoda a zásluhy o rozvoj průmyslu [HHStA, KK, 794/1912].

60 To byl př́pad bratrů Franze (1852-1915), Friedricha (1846-1942) a Isidora (1848-1931) Mayů, společníků cukrovarnické firmy Gebrüder A. und H. May. Šlechtický titul (1914) jim byl - kromě dalšího - udělen za vložení značných, byt’ nespecifikovaných, financí na záchranu Nordösterreichische Bank für Industrie, Handel 
Udělení šlechtictví za poskytnutí financí je možné rozdělit do několika kategorií, a to nejen $\mathrm{z}$ hlediska směřování peněžních prostř̌edků, ale také časového horizontu a kvality zásluh. Od konce 19. se např́klad stále častěji setkáváme s nobilitacemi coby důsledkem péče o vlastní zaměstnance. V prvé řadě šlo o zřizování a příspěvky do úrazových a důchodových fondů, zakládání školek pro děti zaměstnanců nebo výstavbu domů s dotovaným nájemným či bydlením zdarma. ${ }^{61} \mathrm{~V}$ době, kdy stát sociální otázku téměř neřešil a kdy se sociální demokracie stávala silným hráčem na politickém jevišti, šlo z hlediska státních zájmů o mimořádně důležité kroky přispívající ke stabilitě říše [Hamannová 1999: $168-171,183]$.

Dary nebylo nezbytné poskytovat jen v peněžní formě. Někteří zájemci o titul využili situace, kdy měl erár zájem o strategicky či jinak důležitou nemovitost, a de facto ji za šlechtictví vyměnili. ${ }^{62}$ Další věnovali pozemky na veřejně prospěšné budovy (nemocnice, muzea, studentské koleje apod.), nebo je vystavěli na vlastní náklady. ${ }^{63}$ Vysoce ceněny byly také dary armádě, zejména podpůrným fondům pro důstojníky a jejich rodiny nebo Rakouské společnosti bílého křriže (Österreichische Gesellschaft vom Weißen Kreuze), která zajištovala lékařskou a zejména lázeňskou péči o vojáky. ${ }^{64}$ Vzácněji se setkáme i př́mo

und Landwirschaft v Brně, jejíž krach by podle c. k. ministra vnitra barona Heinolda měl vážné následky pro drobné vkladatele velké části Moravy. Heinold přitom zdůraznil, že Mayové v bance neměli vlastní finance, takže by se jich její krach prrímo nedotkl [HHStA, KK, 1585/1914].

61 Humanitární činnost tohoto druhu byla hlavním důvodem udělení Ř́du železné koruny II. třídy a následně baronátu (1869) bankéři Eduardu rytíri von Todesco (1814-1887), který vedle 40000 zl. v rakouských státních dluhopisech pro židovskou nadaci ke zřízení Ústavu slepců v Hernals daroval též 60000 zl. ve státních dluhopisech fondu k podpoře subalterních úředníků [AVA, Inneres, MdI Präsidium, Kt. 1126/1869]. Společníci firmy Haas und Cžjžek, Hans Cžjžek (1841-1925) a Georg Haas (1841-1914) byli povýšeni (1899) do šlechtického stavu mj. za to, že společně zř́idili pro své zaměstnance penzijní fond se vkladem $50000 \mathrm{~K}$ a každoročním příspěvkem ve výši $2000 \mathrm{~K}$ a darovali $20000 \mathrm{~K}$ podpůrnému fondu pro své úředníky a zaměstnance. Haas navíc věnoval $80000 \mathrm{~K}$ Přírodovědně-historickému muzeu ve Vídni a menší částky Červenému kříži. Na rozdíl od Cžjžeka byl Haas povýšen do stavu sv. pánů (1908), ale důvod této nobilitace se nepodařilo dohledat [Haas: AVA, Inneres, MdI Präsidium, Kt. 3819/1899; Cžjžek: HHStA, KK, 1711/1899]. Velkoprůmyslník Adalbert rytíř von Lanna (1836-1909) získal baronát (1907) zejména proto, že věnoval $100000 \mathrm{~K}$ penzijnímu fondu svých úředníků a zaměstnanců, za dar uměleckých předmětů v hodnotě 300000 K Uměleckoprůmyslovému muzeu v Praze a též za zásluhy o rozvoj průmyslu [AVA, Inneres, MdI Präsidium, Kt. 2378/1907, 2379/1907; HHStA, KK, 3041/1907]. Roku 1915 byli do rytířského stavu povýšeni velkoprůmyslníci bratři Emanuel (1868-1929) a Hugo (1872-1937) Grabové, kteří ve své firmě zřídili fond práce neschopné dělníky a úředníky a každoročně jej dotovali $50000 \mathrm{~K}$ [HHStA, KK, 241/1915].

62 To byl prrípad velkoobchodníků v Terstu Julia (1823-1880) a Jacoba (1835-1901) Eisnerů, kteří darovali svou zahradu v Terstu o rozloze 2000 jiter $\left(7,1958 \mathrm{~m}^{2}\right)$ armádě pod podmínkou udělení šlechtictví (1874) [AVA, Inneres, MdI Präsidium, Kt. 1137 a 1138] .

63 Velkoprůmyslník Aron Pollak (1817-1884) získal Ř́d železné koruny III. tř́ídy a následně rytířský titul (1869) při př́ležitosti dokončení Rudolfina, domu pro 75 nemajetných studentů techniky. V jeho př́ípadě však nebylo zjištěno, kolik peněz na stavbu obětoval [Wurzbach 1872, 71-73]. Konkrétní částky známe např. u následujících osob: Robert Fuchs (1854-1925) daroval 200000 K na koupi pozemku pro Uměleckoprůmyslové muzeum v Praze a roku 1912 získal šlechtictví [HHStA, KK, 3099/1912]. Adolf Landsberger (1840-1914) byl do šlechtického stavu (1912) povýšen díky tomu, že věnoval 190000 K Společnosti bílého křriže na zřízení důstojnického domu ve Františkových Lázních a 10000 K rakouskému Slezsku [AVA, Inneres, MdI Präsidium, Kt. 2398/1911; HHStA, KK, 1604/1912]. Max Mandl (1865-1942), roku 1916 povýšený do rytířského stavu, poskytl více než 1 mil. K na vybudování novostavby záložní nemocnice č. 11 ve Vídni [AVA, Inneres, MdI Präsidium, Kt. 2422/1916; HHStA, KK, 1917/1916].

64 Julius Léon (1842-1927) získal (1883) Řád železné koruny III. třídy (a pak rytířský titul) za to, že při př́ležitosti 35. panovnického jubilea Františka Josefa I. daroval $40000 \mathrm{zl}$. Institutu pro důstojnické dcery v Hernalsu [HHStA, KK, 786/1883]. 
s poskytnutím finančních částek armádě. ${ }^{65}$ Vzácné nebyly ale ani věcné dary v podobě potravin či výrobků z vlastních závodů. ${ }^{66}$

Jistou návaznost na starobylé šlechtické tradice a mecenát představuje financování či spolufinancování výstavby kostelů a podpora církve. Toto jednání můžeme vysledovat u všech konfesí, zajímavé specifikum však představuje jednání některých podnikatelů židovské víry. Někteří totiž neváhali kromě židovských obcí podporovat i křest’anské církve, zejména římsko-katolickou. Jejich krok je možné interpretovat několika způsoby: bud’ jako extrémní prrípad náboženské tolerance, nebo jako kalkul chladně uvažujících počtářů, kteří předpokládali, že tímto zpo̊sobem získají sympatie církevních a státních hodnostářů na straně druhé. Vzhledem k těsnému sepjetí habsbursko-lotrinské dynastie s katolickou církví se však domnívám, že šlo o specifickou formu vyjádření loajality panovnickému domu. ${ }^{67}$

Velmi specifický druh sponzorství, řečeno dnešními slovy, představují dary věcného charakteru, většinou uměleckých nebo přírodní sbírek. Nejstarší doklad tohoto jednání máme mezi podnikateli doložen z poloviny 80. let 19. století, kdy Felix Zwicklitz (1836-1901), společník firmy Lindheim \& Co. ve Vídni, daroval Přírodovědně-historickému muzeu ve Vídni prehistorické sbírky v hodnotě přibližně 26000 zlatých a následně vzácné meteority odhadované na 20000 zlatých, které představovaly největší soubor těchto př́rodnin po sbírce uložené v British Museum. ${ }^{68} \mathrm{~K}$ podobným událostem sice nedocházelo př́liš často (v letech 1880 až 1918 byly tyto dary důvodem jen necelých osmi procent

65 Velkoobchodník Gustav Leon (1839-1898) daroval blíže neurčenou částku ve prospěch uherského honvédu, byl (1876) odměněn Řádem železné koruny III. třídy a následně požádal o rytířský titul [HHStA, Obersthofmeisteramt, Orden der Eisernen Krone, Kt. 76/876]. Zajímavý byl případ Julia von Morpurgo (1845-1915), od roku 1898 šlechtice, kterému byl baronát (1913) mj. udělen za finanční podporu vznikajícího rakouského letectva [HHStA, KK, 608/1913]. K jeho osobě viz též níže.

66 Ignazi Eislerovi (1822-1902) bylo uděleno (1901) šlechtictví za mimořádné zásluhy o c. a k. námořnictvo. Tomu postoupil strategicky důležité pozemky na poloostrově St. Pietro v Pule, daroval 40000 zl. na zřízení školky pro děti námořníků a (přestože byl žid) 15000 zl. na výstavbu farního kostela v Pule. Potřebným navíc poskytoval konzervy a chléb [HHStA, KK, 1264/1901].

67 Prokazatelně můžeme tento motiv vysledovat u Maxe Kahlera (1846-1919), který získal (1911) rytíŕský titul především za zásluhy o rozvoj rakouského bankovnictví a burzy a za aktivity v humanitární oblasti. Daroval totiž $50000 \mathrm{~K}$ na stavbu církevních objektů, mj. pamětního kostela zavražděné císařovny Alžběty (Kaiserin-Elisabeth-Gedächtniskirche) na hoře Schneeberg v Dolních Rakousích, kostela ve Vídni a kaple sv. Václava na svém velkostatku ve Svinařích v Čechách [HHStA, KK, 1715/1911]. Bankéř Julius Weisenfeld (1823-1895), bavorský občan usazený v Terstu, získal již roku 1870 Řád železné koruny III. tř́dy a následně rytířský stav (1871) na základě prosby opata a arcibiskupa kongregace mechitaristů (arménská církev), které poskytl půjčku (!) 20000 zl. na založení kláštera v Terstu. Podle memoranda terstského místodržitele K. Möringa (1810-1870) bylo ovšem znění této půjčky formulováno tak, že šlo z poloviny de facto o dar. Udělení řádu bylo podpořeno také dalšími Weisenfeldovými zásluhami o ekonomický rozvoj Terstu a dary během války roku 1866 [AVA, Inneres, MdI Präsidium, Kt. 1130/1869; HHStA, KK, 3546/1869]. Oba muži přitom byli členy židovské obce. Zcela mimořádný byl případ Gustava Redlicha (1852-1908), který také pocházel z židovské rodiny, ale krátce před nobilitací konvertoval ke katolictví. Roku 1902 získal prosté šlechtictví za mimořádné zásluhy o rozvoj cukrovarnictví, zlepšování pracovních podmínek svých zaměstnanců, menší finanční dary (3000 K) na dobročinnost, ale především za dar pozemku a příspěvku na stavbu kostela sv. Alžběty na svém panství Věžky (zřízeného opět na pamět zavražděné císařovny) ve výši 1 mil. K. Velkorysé dary katolické církvi způsobily rodinné firmě ekonomické problémy a roku 1905 byl Redlich donucen vzdát se práva disponovat s většinou svého majetku a předat jeho správu svým synům [HHStA, KK, 2212/1902; AVA, Adelsarchiv, Gustav Redlich, Adelstand (Edler von Vežeg) 1902; Županič 2012: 568-569]. Penězi na stavbu kostela přispěl také výše zmíněný terstský velkoprůmyslník Ignaz Eisler (1901 šlechtic).

68 Za tyto dary získal Zwicklitz roku 1886 šlechtický titul [HHStA, Obersthofmeisteramt, Akten-Hauptreihe, Kt. 1113 (Akten), Hofmuseen, 50-5-3 (Mineralogische-petrographische Abteilung). Županič 2012, 701]. 
zkoumaného vzorku nobilitací), i tak je ale můžeme považovat za významné. Část těchto darů směřovala do císařských muzeí (Přírodovědně-historického a Umělecko-historického) a do císařské obrazárny, tedy institucí podléhajících úřadu nejvyššího hofmistra. Ten jako dvorský úředník nepodléhal žádné vyšší instanci, než samotnému panovníkovi a návrhy na ocenění (včetně nobilitací) proto nemusel předkládat ke schválení ministerské radě. Zjednodušeně řečeno: $\mathrm{v}$ př́ípadě dobrých kontaktů $\mathrm{u}$ dvora či alespoň mezi vedoucími zaměstnanci muzeí a galerie mohlo být schválení nobilitace touto cestou rychlejší a jistější, než pokud šly klasickou úřední cestou.

Většina ocenění za dary uměleckých a př́rodních sbírek ale byla nakonec stejně projednávána na ministerské radě, mj. proto, že v řadě př́padů šlo jen o část zásluh, za které byl podnikatel později vyznamenán. ${ }^{69}$ Mezi tento druh sponzorství můžeme zařadit také nákup významných pozůstalostí, na které stát neměl prostředky a jež přispěly k pozdvižení vědy, př́ípadně přímé dary na financování vědeckého výzkumu. ${ }^{70}$

Nobilitace na základě jednorázové investice patří na rozdíl od opakovaných mezi méně časté, ale nikoli výjimečné. $V$ takových případech však již můžeme předpokládat velmi úzkou kooperaci s úřady (at již se státními, dvorskými či zemskými), protože tyto peníze nebývaly poskytovány na dobročinnost obecně, ale ke konkrétním účelům. Proto také většinou bezprostředně po poskytnutí daru následoval návrh na vyznamenání. Tento postup dokládá i korespondence mezi i nebo obsahy př́slušných memorand s návrhy na vyznamenání. ${ }^{71}$ Setkáme se dokonce s prí́pady, kdy podnikatel poskytnutí finančního daru udělením vyznamenání (napřs šlechtictví) přímo podmínil.72

69 Textilní podnikatel, komerční rada Eduard Doctor (1858-1926) daroval císařské obrazárně významná umělecká díla v celkové hodnotě $250000 \mathrm{~K}$ a velké prostředky poskytl na zlepšení životních podmínek svých zaměstnanců (výstavba domů pro dělníky a úředníky, kde bylo ubytování poskytováno zdarma či s dotovaným nájmem). Na tomto základě byl roku 1911 povýšen do rytířského stavu [AVA, Inneres, MdI Präsidium, Kt. 2398; Županič 2012: 185-186].

70 Horace Landau (1869-1926) daroval císařské Akademii věd $350000 \mathrm{~K}$, ze kterých byly financovány jak archeologické vykopávky v Orientu, tak odkoupení pozůstalosti významného rakouského arabisty dr. Eduarda Glasera. Roku 1912 byl za tento čin povýšen do rytířského stavu [HHStA, KK, 4140/1910; Županič 2012, 451-452). Je přitom zajímavé, že odkoupit Glaserovu sbírky byl ochoten (již za jeho života roku 1894) za udělení šlechtického titulu lvovský velkoobchodník, statkář a majitel realit Samuel Horowitz (1841-1924) a tento krok je také (vedle politické podpory vlády na městské, zemské i řrišské úrovni a velkorysých darů židovské obci) uveden jako jeden z důvodů jeho nobilitace [HHStA, KK, 5236/1894].

71 Bankéř Gustav Epstein (1828-1879) získal Ř́d železné koruny III. tř́idy a rytířský stav (1866) díky participaci na zajištění úvěru, který zajistil splacení válečného odškodnění Prusku, a daru $100000 \mathrm{zl}$. na dobročinné účely [HHStA, KK, 3067/1866; HHStA, Obersthofmeisteramt, Orden der Eisernen Krone. Kt. 54, Nr. 137]. Bernhard Pollack (1847-1911) byl povýšen (1907) do šlechtického stavu za vybudování a financování provozu dvou dětských pavilonů pro 100 pacientů při Nemocnici císaře Františka Josefa (Kaiser Franz Joseph-Spital) ve Vídni. Realizace tohoto projektu jej vyšla na 600000 K [HHStA, KK, 1020/1907]. Felix Stiassny (1867-1938) získal stejný titul (1911) za dar pozemku a částku 200000 K na výstavbu Domu císařovny Alžběty (Kaiserin Elisabethheim) ve Vídni s byty pro 60 osob [AVA, Inneres, MdI Präsidium, Kt. 2383, 2386, 2395 a 2396; HHStA, $K K, 1838 / 1911]$. Ve Stiassného prrípadě se dokonce v MdI dochovala korespondence mezi státními úředníky ohledně formy státního vyznamenání, protože byl původně navržen jen na udělení rytířského kř́iže Řádu Františka Josefa nebo Řádu železné koruny III. třídy. Nakonec ale došlo (nepochybně s přihlédnutím k výši daru) k nobilitaci. Dohodu se státem můžeme předpokládat v př́padě Sigismunda Springera (1873-1928), který získal baronát (1913) za dar 500000 K pro Červený kříž [HHStA, KK, 6/1913]. V jeho př́padě nepochybně sehrál nemalou roli při udělení nečekaně vysokého titulu sňatek s Valentine Noemi (1886-1969), dcerou Alberta Salomona sv. pána von Rothschild (1844-1911). Velmi podrobně je směřování darů zachyceno i u Maxe Mandla (viz výše).

72 Viz výše zmíněná, ale nerealizovaná, nabídka Samuela Horowitze z roku 1894 a též zmíněná nobilitace bratrů Julia a Jacoba Eisnerů (1871). Velmi zajímavý byl př́pad Moritze Doctora (1862-1929). Ten poté, co jeho bratr 
Obtížnou otázku však představuje vyčíslení částky, kterou bylo zapotřebí v případě zájmu o nobilitaci uhradit. Záležitost komplikuje několik faktorů. Především ne všichni podnikatelé, u kterých známe konkrétní výši darů na dobročinnost, získali šlechtický titul pouze na tomto základě. U některých se jednalo o kumulaci zásluh a vynaložená částka proto mohla být nižší, než u jiných. Velkou roli sehrával též zájem státu. Pokud si erár určitou službu přímo vyžádal, bylo možné dosáhnout nobilitace za relativně malé peníze. ${ }^{73}$ Je také velmi obtížné stanovit konkrétní sumu, jež byla za získání titulu vydána, pokud byl závazek platit kontinuální, ${ }^{74}$ nebo když byla peněžní částka doplněna darem nemovitosti s neuvedenou tržní cenou. ${ }^{75}$

Vzorek podnikatelů nobilitovaných výlučně (či téměř výlučně) za finanční dary je bohužel pro jednoznačné závěry prríliš malý. Z 51 př́ípadů, u kterých známe konkrétní částky, totiž bylo jen 28 osob nobilitováno výlučně „za peníze“. Jde tedy jen o necelých 13 procent sledovaného vzorku 216 nobilitací. Navíc se více než 71 procent tohoto počtu (20 př́ípadů) týká povýšení po roce 1898 . Velmi málo tak víme o starším období, zejména o finančním pozadí udílení řádů s nobilitačním paragrafem, protože se potýkáme s fatálním nedostatkem pramenů. ${ }^{76}$

I z tohoto nevelkého celku vyplývá několik skutečností. Je zcela nepochybné, že šlechtický titul bylo možné opravdu získat bez předchozích zásluh, a to na základě jednorázového či opakovaného finančního či věcného daru. Jeho výše závisela na řadě okolností. V př́padě žen bez potomků, kdy bylo jasné, že rod vymře již osobou nobilitované, mohla být částka nižší, ${ }^{77}$ jinak ale vždy hovoříme o darech v hodnotě minimálně 100000 korun (50000 zlatých). Jen titul císařského rady vyšel zájemce na počátku 20. století na 60000

Eduard (viz výše) získal v roce 1911 rytířský titul, zřídil v prosinci 1911 ve prospěch Rakousko-uherského pomocného spolku v Mnichově nadaci ve výši $100000 \mathrm{~K}$. Nadační listina měla vstoupit v platnost teprve poté, co by mu byl udělen šlechtický titul, který také nakonec opravdu (1. 5. 1912) získal [AVA, Inneres, MdI Präsidium, Kt. 2398; HHStA, KK, 1091/1912; Županič 2012: 183-185].

73 Viz výše případ bratrů Eisnerů, kteří nabídli svůj pozemek o rozloze 2000 jiter $\left(7,1958 \mathrm{~m}^{2}\right)$ armádě. Nemovitost přiléhala ke zdejší garnizonní nemocnici a vojsko o něj mělo velký zájem. Přestože byla hodnota pozemku odhadnuta jen na 6000 zl., byl Eisnerům šlechtický titul přesto udělen.

74 Bratři Grabové dotovali fond pro práce neschopné dělníky a úředníky svých závodů ročně 50000 K. Podobně společníci Hans Cžjžek a Georg Haas společně vytvořili společně podpưrný fond pro své úredníky a zaměstnance s kapitálem $20000 \mathrm{~K}$ a penzijní fond ve výši $50000 \mathrm{~K}$ s každoročním příspěvkem ve výši $2000 \mathrm{~K}$. Viz výše.

75 Zmíněný Felix Stiassny daroval na výstavbu Domu císařovny Alžběty nejen $200000 \mathrm{~K}$, ale také stavební parcelu neurčené hodnoty na Blindengasse v osmém vídeňském okrese, Josefstadtu. Přesně nebyl vyčíslen ani dar Franze Czerweného (1848-1921) nobilitovaného roku 1918, který kromě zásluh o rozvoj průmyslu a exportu a sociální opatření ve prospěch vlastních dělníků, daroval roku 1916 Červenému kř́ži zámek Arnfels s hospodářskými budovami a parkem v hodnotě nejméně $410000 \mathrm{~K}$ na léčebnu o 120 lůžkách pro vojáky trpící tuberkulózou [AVA, Adelsarchiv Franz Czerweny, Adelstand (Edler von Arland) 1918].

76 Konkrétní částky známe jen u dvou udělení Řádu železné koruny III. třídy a následně rytířského stavu (Gustav Epstein 1866 - celkem 200000 zl.; Julius Léon 1883 - celkem 80000 zl.) a a dvou II. třídy a baronátu (Eduard rytír von Todesco 1869; Franz rytír von Wertheim 1871 - oba 200000 zl.). Specifický př́pad představuje udělení Řádu železné koruny III. třídy (1864) a následné povýšení do rytířského stavu (1865) bratrů Baltazziů, Spiridiona (1826-1867) a Epaminondase (1828-1887). U nich sice známe výši částky, za kterou vyznamenání získali (4000 zlatých tureckých liber na zřízení rakouské školy v Konstantinopoli), nikoli kurs turecké libry vưči rakouskému zlatému [AVA, Adelsarchiv, Spiridion Baltazzi, Ritterstand (von Kale) 1865; tamtéž, Epaminondas Baltazzi, Ritterstand 1865].

77 Anna von Liebig (1855-1926) zaplatila za baronát „jen“ 92 673,70 K, což byla jinak spodní hranice placená za prosté šlechtictví (viz výše). 
korun. ${ }^{78}$ Povýšení do šlechtického stavu za dary nižší hodnoty byly naprosto výjimečné a s největší pravděpodobností stály v jejich pozadí další, dnes již neznámé okolnosti. ${ }^{79}$

Pokud vyloučíme krajní extrémy ${ }^{80}$ můžeme velmi přibližně vyčíslit průměrné částky, které podnikatelé za svůj společenský vzestup obětovali. Přepočet na dnešní měny je velmi obtížný, ale s přihlédnutí k tehdejší poměrně nízké (až do roku 1915) inflaci, víceméně fixní úrokové sazbě ve výši čtyř procent a stabilitě měny, jejíž prestiž výrazně posílilo zavedení zlatého standardu v rámci nové korunové měny $\mathrm{z}$ roku 1892, můžeme přibližně přepočítat „cenu“ na váhu v mincovním zlatě. ${ }^{81}$

Tabulka 3: Finance vydané podnikateli na dobročinné účely před udělením šlechtického titulu

\begin{tabular}{|l|c|c|}
\hline \multirow{2}{*}{} & \multicolumn{2}{|c|}{ Průměrná „cena“ za titul } \\
\cline { 2 - 3 } & v rakousko-uherských korunách & v kg mincovního zlata \\
\hline šlechtický stav & 174318 & 59,05 \\
\hline rytířský stav & 300000 & 101,63 \\
\hline stav sv. pánů & 450000 & 152,44 \\
\hline
\end{tabular}

Zdroj: vlastní výzkum

Z tabulky 3 vyplývá, že částky, které podnikatelé za své tituly v průměru vydávali, jsou skutečně extrémně vysoké a že si jejich zaplacení mohli skutečně dovolit jen ti nejmajetnější. Jak bude ukázáno níže, šlo o částky většinou převyšující roční příjem nejbohatších obyvatel císařské metropole [Sandgruber 2013]. Někteří z podnikatelů v touze po vzestupu své možnosti dokonce přecenili a dostali se do vážných finančních komplikací. ${ }^{82}$ Přestože

78 Stejným nejvyšším rozhodnutím (z 24. 6. 1912), kterým Adolf Landsberger (1840-1914) získal šlechtický titul, byl Samuelu Scheinovi (1852-1937), majiteli továrny na výrobu koberců a nábytku, udělen titul císařského rady. Zatímco Landsbergerovy dary dosáhly výše $200000 \mathrm{~K}$, Schein při př́ležitosti císařova 60. panovnického jubilea daroval lázeňskému domu pro důstojníky v Rohitsch-Sauerbrunn (dnes Rogaška Slatina), stavěného Jubilejní nadací císaře Františka Josefa I. (Kaiser Franz Joseph I. Jubiläumsstiftung), kompletní inventář (nábytek, závěsy, koberce a ložní prádlo) v hodnotě $25000 \mathrm{~K}$ a dalších $35000 \mathrm{~K}$ v hotovosti (celkem $60000 \mathrm{~K}$ ). Jak vyplývá z interní korespondence ministerstva vnitra a i z Scheinových dopisů, o titul usiloval zejména mj. proto, že byl roku 1907 za urážku na veřejnosti odsouzen k pokutě ve výši 90 zl. (180 K) nebo k trestu vězení v trvání tří dnů. Rozsudek poškozoval jeho pověst podnikatele, a přestože byl již na titul císařského rady dříve navržen, nebyl mu pro jeho prohřešek udělen [AVA, Inneres, MdI Präsidium, Kt. 2398/1911].

79 Ze sledovaného celku jde o dvě osoby. První byl Hans Cžjžek (1841-1914), který se svým společníkem Georgem Haasem společně zřídil pro zaměstnance již zmíněný penzijní a podpůrný fond v celkové výši $70000 \mathrm{~K}$ a s ročním příspěvkem $1000 \mathrm{~K}$. Nelze však vyloučit, že většinu této částky uhradil on sám, protože jeho společník Haas navíc daroval $80000 \mathrm{~K}$ Př́rodovědně-historickému muzeu ve Vídni. Možné je ale i to, že Cžjžek státu poskytl ještě další služby, jejichž podobu a rozsah neznáme [HHStA, KK, 1711/1899].

80 Nejnižší částku za prosté šlechtictví zaplatil Hans Cžjžek (35 000 K), nejvyšší Bernhard Pollack (600 000 K). Za rytířský titul nejvíce peněz (1 mil. K) vydal Max Mandl a za baronát nejméně ( 92673,70 K) Anna von Liebig. Jinak se částky za rytířský stav a baronát pohybují přibližně ve stejné rovině (průměr uveden níže).

81 Rakousko-Uhersko užívalo pro ražbu svých zlatých mincí po zavedení korunové měny (1892) tzv. mincovní zlato o ryzosti 900/1000 (21,6 karátů). Největší mince, stokoruna, obsahovala 33,8753 g zlata. Částky v penězích jsou zaokrouhleny na celé koruny.

82 To byl př́pad moravského cukrovarníka Adolfa Kürschnera (1844-1915), jehož firma na přelomu 19. a 20. století patřila mezi nejúspěšnější v monarchii. Roku 1908 byl z blíže neznámých důvodů povýšen do rakouského šlechtického stavu, což ale jeho ctižádost neuspokojilo. Údajně usiloval o rakouský stav svobodných pánů, za který byl ochoten prostředníkovi zaplatit 1 mil. K. Později ale přijal uherské občanství a dohodl se s uherskou vládou premiéra Khuen-Héderváryho na daru 800000 K na dobročinné účely. I tento plán se nakonec změnil, 
z tabulky vyplývá, že mezi „cenou“ jednotlivých titulů byly značné rozdíly, nevládla mezi velikostí daru a uděleným titulem není vždy přímá úměra. Zejména v případě nižší šlechty (prostých šlechticů a rytíruo se jedná o střední hodnotu, jež vznikla vyloučením extrémních částek. Průměrná suma placená za udělení prostého šlechtictví sice činila necelých 175000 korun, ale osm ze 17 jedinců nobilitovaných tímto způsobem zaplatilo více: pět po 200 000, dva přes 300000 a jeden dokonce plných 600000 korun. ${ }^{83}$ Podobně vyhlížela situace u rytířského stavu, kde jeden z donátorů zaplatil o $700000 \mathrm{~K}$ více, než činil průměr. ${ }^{84}$

Velkorysosti se samozřejmě meze nekladly, zároveň je však málo pravděpodobné, že by donátoři byli tak skromní a spokojili s nižším titulem, pokud mohli získat vyšší. Pravděpodobnější proto je, že si podnikatel byl schopen nobilitaci určitým způsobem vyjednat, ale méně již byl schopen ovlivnit, jaký titul získá. Podobně jako u úředníků i zde byla zásadní pozice na společenském žebříčku a od ní se odvíjející faktory: kontakty na nejvyšších místech, př́ibuzenské vazby ke šlechtě a nobilitace př́ibuzných. ${ }^{85}$

Výše majetku proto při udílení šlechtictví nehrála prvořadou úlohu. To ostatně ukazuje i následující tabulka zachycující k roku 1910 roční př́ijmy ve Vídni usazených podnikatelů nobilitovaných v letech 1907 až $1914 .{ }^{86}$ Údaje byly dohledány u celkem 16 osob, ze kterých bylo devět povýšeno do šlechtického, čtyři do rytířského a tři do stavu svobodných pánů. Rozdíly v př́ijmech mezi nimi jsou sice nemalé, rozhodně však nekorespondují s udělenými tituly.

Tabulka 4: Př́ímy vídeňských podnikatelů nobilitovaných v letech 1907 až 1917 k roku 1910

\begin{tabular}{|l|c|c|c|c|}
\hline Jméno & $\begin{array}{c}\text { Datum nobilitace } \\
\text { (listiny) }\end{array}$ & $\begin{array}{c}\text { Udělený } \\
\text { stav }^{87}\end{array}$ & Predikát & $\begin{array}{c}\text { Výše ročního } \\
\text { př́ijmu v K (1910) }\end{array}$ \\
\hline $\begin{array}{l}\text { Krones, Anton } \\
(1848-1912)\end{array}$ & $\begin{array}{c}1911,21.12 . \\
(1912,2.1 .)\end{array}$ & $\check{S}$ & $\begin{array}{c}\text { šlechtic von } \\
\text { Lichtenhausen }\end{array}$ & 112809 \\
\hline $\begin{array}{l}\text { Stiassny, Felix } \\
(1867-1938)\end{array}$ & $\begin{array}{c}1911,9.6 . \\
(1911,28.7 .)\end{array}$ & $\check{S}$ & $\begin{array}{c}\text { šlechtic von } \\
\text { Elzhaim }\end{array}$ & 116323 \\
\hline $\begin{array}{l}\text { Fröhlich, Arnold } \\
(1839-1924)\end{array}$ & $\begin{array}{c}1914,19.3 . \\
(1914,4.5 .)\end{array}$ & $\check{S}$ & $\begin{array}{c}\text { šlechtic von } \\
\text { Fanyon }\end{array}$ & 121354 \\
\hline
\end{tabular}

protože Adolf vyjednal přímo s uherským ministerským předsedou příspěvek do pokladny nově vytvořené uherské Národní strany práce, který byl nižší, než původně uvažovaný dar na dobročinné účely. Po zisku baronátu (1910) se Kürschner dostal do finančních problémů a roku 1913 jeho firmu Kürschner \& Co. převzaly banky Creditanstalt a Länderbank, jež ji transformovaly ve Středomoravskou akciovou společnost cukrovarnickou. Podle tisku měl být důvodem úpadku právě Kürschnerův rozmařilý životní styl [Pester Lloyd, 18. 3. 1913 (Abendblatt), s. 2; Gaugusch 2011: 1609-1613].

83 Bernhard Pollack (1847-1911) nobilitovaný roku 1907.

84 Max Mandl (viz výše) zaplatil za udělení rytírského titulu (1916) více než 1 mil. K.

85 U Heinricha Keila (1856-1914), od 1908 šlechtice, bylo zdůrazněno, že je př́buzným roku 1855 nobilitovaného polního podmaršálka Heinricha rytíře von Keil [HHStA, KK, 1718/1908]. Když byli do šlechtického stavu (1913) povýšeni jeho bratři Eduard (1854-1926) a Viktor (1860-1923), byla naopak v memorandu zmíněna Heinrichova nobilitace a skutečnost, že se jedna Viktorova dcera provdala za barona Rokitanského [HHStA, KK, 856/1913].

86 Údaje o př́ijmech k roku 1910 uvádí Sandgruber 2013, 306-469. Vycházíme přitom z předpokladu, že př́ijmy těchto osob byly v uvedeném období s malými odchylkami konstantní.

87 Š = šlechtický, R = rytířský, SP = stav sv. pánů. 
JAN ŽUPANIČ Sociální vzestup podnikatelů v Rakouském císařství

\begin{tabular}{|c|c|c|c|c|}
\hline $\begin{array}{l}\text { Krassny, Maxime } \\
(1858-1936)\end{array}$ & $\begin{array}{c}1911,6.1 . \\
(1911,14.2 .)\end{array}$ & $\check{S}$ & $\begin{array}{l}\text { šlechtic von } \\
\text { Krassien }\end{array}$ & 138150 \\
\hline $\begin{array}{l}\text { Doctor, Moritz } \\
(1862-1929)\end{array}$ & $\begin{array}{c}\text { 1912, 1. 5. (1912, } \\
\text { 8. 6.) }\end{array}$ & $\check{S}$ & $\begin{array}{l}\text { šlechtic von } \\
\text { Hohenlangen }\end{array}$ & 159824 \\
\hline $\begin{array}{l}\text { Neumann, Adolf } \\
(1847-1922)\end{array}$ & $\begin{array}{c}1913,27.2 .(1913, \\
\text { 23. 4) }\end{array}$ & $\check{S}$ & $\begin{array}{l}\text { šlechtic von } \\
\text { Ditterswaldt }\end{array}$ & 191445 \\
\hline $\begin{array}{l}\text { Benda, Gustav } \\
(1846-1932)\end{array}$ & $\begin{array}{c}1911,12.7 \\
(1911,7.12 .)\end{array}$ & $\check{S}$ & šlechtic von & 256986 \\
\hline $\begin{array}{l}\text { Pollack, Bernhard } \\
(1847-1911)\end{array}$ & $\begin{array}{c}1907,5.4 .(1907 \\
\text { 29. 4.) }\end{array}$ & $\check{S}$ & $\begin{array}{l}\text { šlechtic von } \\
\text { Parnau }\end{array}$ & 499637 \\
\hline $\begin{array}{l}\text { Redlich, Theodor } \\
(1850-1922)\end{array}$ & $\begin{array}{c}1911,7.5 . \\
(1911,20.7)\end{array}$ & $\check{S}$ & šlechtic von & 619974 \\
\hline $\begin{array}{l}\text { Doctor, Eduard } \\
(1858-1926)\end{array}$ & $\begin{array}{l}1911,21.11 . \\
(1911,5.12 .)\end{array}$ & $\mathrm{R}$ & - & 288067 \\
\hline $\begin{array}{l}\text { Suess, Friedrich } \\
(1864-1938)\end{array}$ & $\begin{array}{l}1908,6.11 \\
(1909), 6.5 .\end{array}$ & $\mathrm{R}$ & Hellrat & 119500 \\
\hline $\begin{array}{l}\text { Landau, Horace } \\
(1869-1926)\end{array}$ & $\begin{array}{l}1910.27 .12 . \\
(1911,18.3 .)\end{array}$ & $\mathrm{R}$ & - & 411300 \\
\hline $\begin{array}{l}\text { Morawitz, Karl } \\
(1846-1914)\end{array}$ & $\begin{array}{c}1913,2.11 \\
(1914,25.2 .)\end{array}$ & $\mathrm{R}$ & - & 1138211 \\
\hline $\begin{array}{l}\text { Fould, Eugène } \\
(1876-1929)\end{array}$ & $\begin{array}{l}1908,18.3 . \\
(1908,3.4 .)\end{array}$ & SP & - & 152326 \\
\hline $\begin{array}{l}\text { Springer, } \\
\text { Sigismund } \\
(1873-1928)\end{array}$ & $\begin{array}{c}1913,3.1 . \\
(1913,8.2 .)\end{array}$ & SP & - & 243535 \\
\hline $\begin{array}{l}\text { Wertheim, Franz } \\
\text { ml. šlechtic von } \\
(1865-1925)\end{array}$ & $\begin{array}{l}1913,12.7 \\
(1913,5.9 .)\end{array}$ & $\mathrm{SP}$ & - & 262712 \\
\hline
\end{tabular}

Zdroj: [Sandgruber 2013]

Zvlášt zajímavé jsou relativně nízké př́ijmy tř́i nově povýšených baronů. Ani jeden nepatřil po této stránce př́imů mezi top elitu - Fould stál mezi 929 nejbohatšími obyvateli Vídně na 487, Springer na 239 a Wertheim na 203 místě [Sandgruber 2013: 341, 444, 460]. Jenže na Foulda byl stav svobodných pánů přenesen z jeho tchána barona Gustava von Springer (1842-1920), čtvrtého nejbohatšího muže Vídně, ${ }^{88}$ protože byl manželem jeho jediné dcery Marie Cäcilie (1886-1978). Springer se stal baronem hlavně díky tomu, že se stal zetěm Alberta Salomona svobodného pána von Rothschild (1844-1911). ${ }^{89}$ Specifický byl pak prŕpad Franze Wertheima (1865-1925), který byl jako nemanželský syn a univerzální dědic jednoho z předních rakouských průmyslníků barona Franze von Wertheim

88 Roku 1910 udával př́ijem ve výši 4123906 K. Tamtéž, s. 444. Jeho žádost a přenesení titulu in: HHStA, KK, 849/1908; AVA, Adelsarchiv, Springer, Adelsakt 1868-1908.

89 Vzhledem k jeho ročním př́ímům je možné, že na jednorázový dar ve výši $500000 \mathrm{~K}$ pro Červený kříž, na jehož základě titul získal, použil i rothschildovské finance [HHStA, KK, 6/1913]. 
(1818-1883), po otcově smrti povýšen do nejprve do šlechtického stavu a později i mezi svobodné pány. ${ }^{90}$

Vynikající společenské kontakty jsou ostatně společné všem novým baronům z řad podnikatelů, kteří svůj titul získali po zrušení nobilitačních paragrafů roku 1884 . V deseti př́padech, které v našem vzorku 216 nobilitací najdeme, byli jen dva muži (Fould a Springer) povýšeni do stavu svobodných pánů rovnou. Čtyři jedinci ${ }^{91}$ pocházeli z dříve nobilitovaných rodů a čtyři byli povýšeni nejdřív na šlechtice a pak na barony. Všichni z této druhé čtveřice ale měli blízké př́ibuzné z řad vyšší šlechty - a to bud' mezi předky a příbuznými, ${ }^{92}$ nebo mezi partnery svých dětí. ${ }^{93}$

Udílení šlechtictví za peníze či věcné dary můžeme s určitou nadsázkou označit za odpustky moderní doby. Podnikatel však neusiloval o spásu své duše, ale o sociální vzestup, a neplatil církvi, ale státu, jenž na tomto základě „odpustil“ jinak vyžadovanou dlouholetou a bezúhonnou činnost v jeho službách. Dary od podnikatelů plynuly do celé řady odvětví, které Rakousko nebylo jinak schopno financovat: na sociální účely, vytváření penzijních a úrazových fondů pro zaměstnance, koupě uměleckých a přírodovědných sbírek a důležitých pozůstalostí či na záchranu krachujících bank a záložen. Z hlediska státních zájmů šlo o logický krok, který vedl k úspoře rozpočtových zdrojů, hrál roli při snižování sociálního napětí a mohl mít i kladné politické důsledky.

Jak ukazuje udělení knížecího stavu Karlu Josephu hraběti von Palm-Gundelfingen ${ }^{94}$ (1749-1814) z roku 1783, můžeme nobilitace tohoto typu vzácně doložit již ve starší době. Nikoli ovšem v takové míře, jako ve druhé polovině 19. století. V této době navíc byla společnost zásadně odlišná, a přestože udílení šlechtictví nadále zůstávalo výsadou panovníka, dostávalo se stále více do centra pozornosti veřejného mínění. Zachování této instituce coby reliktu feudalismu totiž nekonvenovalo s názorem velké části populace podunajské monarchie, jak ostatně ukázalo i jednání Kroměřížského sněmu. ${ }^{95}$

90 Narodil se jako Franz Gunst a jméno Wertheim přijal až po smrti svého biologického otce. Šlechtický titul získal roku 1886, baronát roku 1913 [AVA, Inneres, MdI, Präsidium, Kt. 1156/1886; AVA, Adelsarchiv, Franz Wertheim, Adelsakt 1886-1913].

91 Včetně manžela jediné nobilitované ženy: Anny von Liebig (sv. paní 1916).

92 Otec Franze Wertheima byl baron (viz výše). Julius Morpurgo (1845-1915) sice mezi přímými předky šlechtice neměl, zato však rodina Parente, ze které pocházela jeho matka, byla nobilitována hned ve dvou liniích (baronské a šlechtické). Morpurgo (1898 šlechtic, 1913 sv. pán) měl ve srovnání s ostatními další přednosti. Přestože byl rakouským občanem, žil trvale v Pařiži, kde prokazoval monarchii významné služby. Patřil také mezi přední sponzory vznikajícího rakouského letectva [AVA, Inneres, MdI, Kt. 2386/1908, HHStA, KK, 608/1913].

93 Při udělení baronátu (1911) Leopoldu Alexanderovi Hauptovi von Buchenrode (1827-1904) byla zdůrazněna skutečnost, že na jednoho z jeho synů byl roku 1888 přenesen uherský baronát jeho tchána Augusta Stummera de Tavarnok, a druhý se oženil s baronkou von Phull [HHStA, KK, 758/1901; AVA, Adelsarchiv, Leopold Haupt, Adelstand (Edler von Buchenrode) 1875; tamtéž, Leopold Alexander Haupt Edler von Buchenrode, Freiherrnstand 1901]. Pouze humanitární zásluhy jsou při udělení baronátu (1918) zmíněny jen u Leopolda Pollacka von Parnegg, přestože i jeho děti měli partnery mezi vyšší šlechtou [AVA, Inneres, MdI, Kt. 2441/1918; HHStA, KK, 1170/1918].

94 Karl Joseph hrabě von Palm-Gundelfingen byl do říšského knížecího stavu povýšen za dar celkem 740000 zl. konvenční měny na humanitární účely [Klein 1987: 181-182].

95 Ústavní výbor nakonec paragraf o zrušení šlechtických titulů nepřijal většinou pouhého jediného hlasu [Teska 2007, 30-31]. 
Přestože právo udílet a užívat šlechtictví zůstalo i po roce 1848 zachováno, diskuse o oprávněnosti jeho existence neustala. Poměrně dlouhou dobu byly kritizovány zejména řády s nobilitačním paragrafem, kdy po udělení vznikal nárok na šlechtický titul - tedy dvojí odměňování týchž zásluh. Po zrušení tohoto předpisu roku 1884 byl napadán zejména dědičný charakter nobilitací, který z ocenění jednotlivce činil výsadu i pro následující generace. V souvislosti se zásadní proměnou společnosti ve druhé polovině 19. století měl totiž šlechtický titul u mnoha osob výrazně menší respekt, než vlastní pílí dosažené (a nedědičné) společenské postavení. ${ }^{96}$

Napadána tedy byla především forma šlechtictví, nikoli důvody jeho udílení. Zejména u důstojníků, ale také u úředníků byla nobilitace často chápána jako ocenění náročné, nepř́liš skvěle placené a obvykle celoživotní služby. U podnikatelů ale byla situace odlišná. Protože jejich pracovní činnost nebyla většinou šlechtickými tituly oceňována, museli získat zásluhy jiného charakteru. To nebylo zrovna lehké. Pokud se pustili do politických aktivit, vystavovali se riziku kritiky za př́lišnou úslužnost státní moci, což byl ale př́ípad všech osob spojených s tímto odvětvím veřejného života. ${ }^{97}$ Ovšem mnohem vážnější situace nastala ve chvíli, kdy titul získali za peníze. Takový postup nebyl veřejností (a to nejen v Rakousku) chápan jako pomoc státu, ale jako obyčejný obchod, který hodnotu šlechtictví degradoval. Situaci v řadě př́ípadů zhoršovala i arogance některých zbohatlíků, kteří svůj majetek vystavovali ostentativně na odiv a kteří dávali najevo, že si za své peníze mohou koupit nejen zámky a velkostatky, ale také postavení a tituly. Vzhledem k velkorysosti při udílení šlechtictví byl sice takový postup v Rakousku tolerován více, než napríklad v Prusku, kde se podobné obchody staly předmětem ostré kritiky řady žurnalistů [Županič Fiala 2017: 132-135, 168-175], ale i zde vedly k vážnému poklesu instituce šlechtictví a nepochybně přispěly k jeho zrušení po rozpadu monarchie roku 1918.

\section{Poděkování}

Tato studie vznikla v rámci grantu Grantové agentury České republiky č. 18-00386S.

\section{Bibliografie}

\section{Nevydané prameny}

Bayrisches Hauptstaatsarchiv, Adelsmatrikel - v textu: BayHStA, Adelsmatrikel.

Geheimes Staatsarchiv Preußischer Kulturbesitz, I. HA Rep. 176 Heroldsamt - v textu GStA, Heroldsamt. Magyar Nemzeti Levéltár, K 20 - Király Személye Körüli Minisztérium Levéltára - Elnöki iratok, K 20 v textu: $M N L, K 20$.

Národní archiv, Ministerstvo vnitra Vídeň, Šlechtický archiv - v textu: $N A, \breve{S} A$.

96 Známý je výrok Rudolfa Siegharta (1866-1934), šedé eminence rakouských vlád přelomu 19. a 20. století a od roku 1910 šéf banky Bodencreditanstalt, který prohlásil, že se „cítil lépe jako místě sekčního šéfa, než jako nově upečený baron“ [cit. dle: Sieghart 1932: 127].

97 Když byl např. vůdce moravských Čechů Alois Pražák (1820-1901), který ve vládě Eduarda Taaffeho zastával úrad ministra spravedlnosti a českého ministra-krajana, povýšen do stavu svobodných pánů, prohlásil tehdejší poslanec českého zemského sněmu a později profesor českých dějin na pražské univerzitě Josef Kalousek (1838-1915), že „na něj hledí jako na panu po pádu“ [cit. dle Heidler 1926: 537]. František Ladislav Rieger (1818-1901) se dokonce po podání žádosti o udělení baronátu roku 1897 dostal do ostrého sporu se svými dětmi, které tento krok odmítaly [Novotný 2014]. 
Österreichisches Staatsarchiv, Allgemeines Verwaltungsarchiv, Adelsachiv (1500 ca - 1918 ca), Hofkadelsakten (1600-1918), Akten - v textu: AVA, Adelsarchiv.

Österreichisches Staatsarchiv, Allgemeines Verwaltungsarchiv, Inneres (1550 ca - 1918), Ministerium des Innern (1848-1918), Präsidium (1848-1918), Akten - v textu: AVA, Inneres, MdI, Präsidium.

Österreichisches Staatsarchiv, Allgemeines Verwaltungsarchiv, Inneres (1550 ca - 1918), Ministerratspräsidium (1860-1918), Ministerratspräsidium, Akten - v textu: AVA, Ministerratspräsidium.

Österreichisches Staatsarchiv, Haus-, Hof- und Staatsarchiv, Hofarchive, Privat- und Familienfonde, Obersthofmeisteramt (13. Jh. - 1921), Obersthofmeisteramt (1650-1921), Akten-Hauptreihe - v textu: HHStA, Obersthofmeisteramt, Akten-Hauptreihe.

Österreichisches Staatsarchiv, Haus-, Hof- und Staatsarchiv, Hofarchive, Privat- und Familienfonde, Obersthofmeisteramt (13. Jh. - 1921), Obersthofmeisteramt (1650-1921), Orden der Eisernen Krone (1816-1918), Akten - v textu: HHStA, Obersthofmeisteramt, Orden der Eisernen Krone.

Österreichisches Staatsarchiv, Haus-, Hof- und Staatsarchiv, Kabinettsarchiv (1523-1918), Kabinettskanzlei (1683-1918), Kabinettskanzlei Vorträge (1848-1918), Akten - v textu: HHStA, KK.

\section{Vydané prameny}

Die Ergebnisse der Volkszählung vom 31. December 1880 [1884], Wien, Heft 3.

Volkszählung vom 31. Dezember 1910 [1917], Wien, Heft 1.

\section{Tisk}

Neues Wiener Tagblatt

Pester Lloyd

\section{Literatura}

Arnbom, Marie-Therese [2002]. Friedmann, Gutmann, Lieben, Mandl und Strakosch: fünf Familienporträts aus Wien vor 1938. Wien - Köln - Weimar: Böhlau Wien.

Berghoff, Hartmut [1994]. Aristokratisierung des Bürgertums? Zur Sozialgeschichte der Nobilitierungen von Unternehmern in Preußen und Großbritannien 1870 bis 1918. Vierteljahrschrift für Sozial- und Wirtschaftsgeschichte 81: 178-204.

Binder-Krieglstein, Reinhard [2000]. Österreichisches Adelsrecht. Von der Ausgestaltung des Adelsrechts der cisleithanischen Reichshälfte bis zum Adelsaufhebungsgesetz der Republik unter besonderer Berücksichtigung des adeligen Namensrechts. Frankfurt am Main: Peter Lang.

Brňovják, Jiří [2015]. Šlechticem z moci úřední. Udělování šlechtických titulư v českých zemích (1705-1780). Ostrava: Ostravská univerzita.

Drewes, Kai [2013]. Jüdischer Adel. Nobilitierungen von Juden im Europa des 19. Jahrhunderts. New York - Frankfurt am Main: Campus Verlag.

Engel-Janosi, Friedrich [1974]. ... aber ein stolzer Burger. Erinnerungen aus einer verlorener Generation. Graz: Verlag Styria.

Ernst, Marcus D. [2001]. Der bayerische Adel und das moderne Bayern. Die Gesetzgebung und Debatte über die persönlichen Privilegien des in Bayern immatrikulierten Adels (1808-1818). Inaugural-Dissertation, Universität Passau.

Feigl, Helmuth [1991]. Die Stellung des Adels nach 1848 im Spiegel der Gesetzgebung. In. Feigl, Helmuth Rosner, Willibald (ed.). Adel im Wandel. Vorträge und Diskussionen des elften Symposiums des Niederösterrreichischen Instituts für Landeskunde Horn, 2.-5. Juli 1990. Wien, s. 117-135.

Fessen [1974]. Alfred, Der österreichische Wirtschaftsadel von 1909-1918. Dissertation zur Erlangung des Doktorgrades an der philosophischen Fakultät der Universität Wien, Wien.

Frank-Döfering, Peter [1989]. Adelslexikon des Österreichischen Kaisertums 1804-1918. Wien - Freiburg - Basel: Herder.

Gaugusch, Georg [2011]. Wer einmal war. Das jüdische Grossbürgertum Wiens 1800-1938, A-K. Wien: Amalthea.

Gaugusch, Georg [2015]. Der jüdische Hausbesitz in der Wiener Innenstadt und der Ringstraßenzone bis 1885. In. Kohlbauer-Fritz, Gabriele (ed.). Ringstrasse. Ein jüdischer Boulevard. Wien, s. 89-134.

Gaugusch, Georg [2016]. Wer einmal war. Das jüdische Grossbürgertum Wiens 1800-1938, L-R. Wien: Amalthea. 
Gaugusch, Georg [2019]. Die kaiserliche Entschließung vom 18. Juli 1884. In. Pangerl, Irmgard - Röhsner, Zdislava (ed.). Zwischen Archiv und Heraldik. Festschrift für Michael Göbl zum 65. Geburtstag. Wien: Heraldisch-Genealogische Gesellschaft Adler, s. 79-89.

Göbl, Michael [1983-1985]. Die Wappenverleihung an Arthur Krupp im Jahre 1907 und der Versuch einer Neueinführung von bürgerlichen Wappenbriefen. Adler. Zeitschrift für Genealogie und Heraldik 13 (XXVII.), Bd. 1983-1985: 3-4.

Godsey, William D. [2017]. Adelige Intoleranz. Die antijüdische Aufnahmeordnung des niederösterreichischen Ritterstandes aus dem Jahr 1808. In. Keller, Katrin - Mata, Petr - Scheutz, Martin (ed.). Adel und Religion in der frühneuzeitlichen Habsburgermonarchie. Wien: Böhlau, s. 321-337.

Granichstaedten-Czerva, Rudolf [1954]. Geadelte Frauen. Monatsblatt Adler. Zeitschrift für Genealogie und Heraldik 8: 104-106.

Hájek, Jan - Matoušek, Václav [2019]. Ringhofferové v kontextu obecného fenoménu rekreačních („venkovských" aktivit buržoazních elit v 19. a na počátku 20. století). In. Hlavačka, Milan - Hořejš, Miloš. Fenomén Ringhoffer. Rodina, podnikání, politika. Praha: Národní technické muzeum.

Hamannová, Brigitte [1999]. Hitlerova Vídeň. Diktátorova učednická léta. Praha: Prostor.

Heidler, Jan (ed.) [1926]. Př́ispěvky k listáři Dra Frant. Lad. Riegra, díl II. Praha: Historický archiv České Akademie.

Hertz-Eichenrode, Dieter [2006]. Wilheminischer Neuadel? Zur Praxis der Adelsverleihung in Preußen vor 1914. Historische Zeitschrift 282 (3): 645-679.

Jäger-Sunstenau, Hanns [1963]. Statistik der Nobilitierungen in Österreich 1701-1918. In. Österreichisches Familienarchiv, Bd. 1. Neustadt an der Aisch: Degener-Verlag, s. 3-16.

Kerschbaumer, Arno [2017]. Nobilitierungen unter der Regentschaft Kaiser Franz Josef I. / I. Ferenc József király (1914-1916). Graz.

Kerschbaumer, Arno [2017]. Nobilitierungen unter der Regentschaft Kaiser Karl I. / IV. Károly király (1916-1921). Graz: Arno Kerschbaumer.

Klein, Thomas [1987]. Die Erhebungen in den weltlichen Reichsfürstenstand 1550-1806. In. Walter Heinemeyer (ed.). Vom Reichsfürstenstande, Köln-Ulm: Selbstverlag des Gesamtvereins der Deutschen Geschichts- und Altertumsvereine, s. 137-192.

Komanovits, Renate [1974]. Der Wirtschaftsadel unter Kaiser Franz II. (I.) in der Zeit von 1792 bis 1815. Dissertation zur Erlangung des Doktorgrades an der philosophischen Fakultät der Universität Wien, Wien.

Konecny, Elvira [1986]. Die Familie Dumba und ihre Bedeutung für Wien und Österreich. Dissertation zur Erlangung des Doktorgrades der Philosophie an der geistenwissenschaftlichen Fakultät der Universität Wien, Wien.

Kučera, Rudolf [2012]. Staat, Adel und Elitenwandel. Die Adelsverleihungen in Schlesien und Böhmen 1806$1871 \mathrm{im}$ Vergleich. Göttingen - Bristol, CT, USA: Vandenhoeck \& Ruprecht.

Laich, Mario [1993]. Altösterreichische Ehrungen - Auszeichnungen des Bundes. Vergleiche und Betrachtungen. Ein Beitrag zur Rechts- und Kulturgeschichte. Innsbruck - Wien: Tyrolia-Verlag.

Matějček, Jiří [1994]. K metodice výzkumu sociální skupiny podnikatelu․ Podnikatel v systému sociální stratifikace. In. Myška, Milan (ed.). Podnikatelstvo jako předmět historického výzkumu (Protokoly kolokvií, konaných ve dnech 2.-3. prosince 1992 a 9.-10. prosince 1993 v Ostravě). Ostrava: Filozofická fakulta Ostravské univerzity.

Mayrhofer, Ernst - Pace, Anton Graf [1901]. Handbuch für den politischen Verwaltungsdienst der im Reichsrate vertretenen Königreiche und Länder mit besonderer Berücksichtigung der diesen Ländern gemeinsamen Gesetze und Verordnungen, 5. Wien, s. 114-168.

Megner, Karl [1974]. Zisleithanische Adels- und Ritterstandserwerber 1868-1884. Hausarbeit am Institut für österreichische Geschichtsforschung, Wien.

Megner, Karl [1985]. Beamte. Wirtschafts- und sozialgeschichtliche Aspekte des k. k. Beamtentums. Wien: Verlag der Osterreichischen Akademie der Wissenschaften.

Myška, Milan [2002]. „Nová šlechta“ z řad peněžníků, obchodníků a průmyslníků v českých zemích v 19. století. (Poznámky - problémy - perspektivy výzkumu). In. Pocta Janu Janákovi. Brno: Matice moravská, s. 355-361.

Novotný, Robert R. [2014]. Nobilitace Františka Ladislava Riegera. In. Županič, Jan - Fiala, Michal Koblasa, Pavel (ed.). Šlechtický archiv c. k. ministerstva vnitra - Erbovní listiny Národního archivu, 
Státního oblastního archivu v Praze, Archivu hlavního mèsta Prahy (dodatky), Archivu Národního muzea (dodatky). Praha: Agentura Pankrác, s. 66-81.

Popelka, Petr [2011]. Zrod moderního podnikatelstva. Bratři Kleinové a podnikatelé v českých zemích a Rakouském císařství v ére kapitalistické industrializace. Ostrava: Filozofická fakulta Ostravské univerzity v Ostravě.

Pouzar, Vladimír [2006]. Rok 1848 - přelom v udělování rakouských záslužných řádů. In. Heraldická ročenka 2006. Praha: Heraldická společnost, s. 149-162.

Putz, Franz [1975]. Die österreichische Wirtschaftsaristokratie von 1815-1859, Dissertation zur Erlangung des Doktorgrades an der philosophischen Fakultät der Universität Wien, Wien.

Sandgruber, Roman [2013]. Traumzeit für Millionäre: Die 929 reichsten Wienerinnen und Wiener im Jahr 1910. Wien - Graz - Klagenfurt: Styria Premium.

Schumann, Dirk [1992]. Wirtschaftsbürgertum in Deutschland: segmentiert und staatsnah. Bemerkungen zu den Erträgen, Problemen und Perspektiven der neueren deutschen Unternehmersgeschichte. Österreichische Zeitschrift für Geschichtswissenschaft 3 (3): 375-384.

Sieghart, Rudolf [1932]. Die letzten Jahrzente einer Grossmacht. Menschen, Völker, Probleme des Habsburger-Reichs. Berlin: Verlag Ullstein.

Smutný, Bohumír [1998]. Loscani a Chamaré o východočeském plátenictví: studie o hospodářské politice habsburské monarchie mezi slezskými válkami a válkou sedmiletou a edice korespondence zlet 1754-1757. Zámrsk: Státní oblastní archiv Zámrsk.

Stein, Hans Konrad [1982]. Der preußische Geldadel des 19. Jahrhunderts. Untersuchungen zur Nobilitierungspolitik der preussischen Regierung und zur Anpassung der oberen Schichten des Bürgertums an den Adel, Disertation an der Universität Hamburg, Hamburg.

Stögmüller, Hans [2010]. Josef Werndl und die Waffenfabrik in Steyr. Steyr: Verlag Ennsthaler.

Teska, Vojtěch [2007]. Kroměřižský sněm a tzv. kroměř́žzká ústava, Diplomová práce, Univerzita Karlova v Praze, Právnická fakulta, Praha.

Wehler, Hans-Ulrich [1995]. Deutsche Gesellschaftsgeschichte, Band 3: Von der „Deutschen Doppelrevolution" bis zum Beginn des Ersten Weltkrieges 1849-1914. München: C. H. Beck.

Weimarer historisch-genealoges Taschenbuch des gesamten Adels jehuäidischen Ursprungs [1912]. Weimar: Kyffhäuser-Verlag.

Witting, Johann Baptist [1898]. Statistik der Standeserhöhungen während der Regierung Seiner Majestät des Kaisers Franz Josef I. In. Festschrift zum fünfzigjärigen Regieruns-Jubiläum (1848-1898) Seiner kaiserlichen und königlichen apostolischen Majestät Franz Josef I. (Hrsg. von Historischen Vereinen Wiens im Selbstverlage des Vereines für Landeskunde von Niederösterreich), Wien, s. 59-91.

Wrede, Alphons Freiherr von [1898]. Geschichte der k. und k. Wehrmacht: die Regimenter, Corps, Branchen und Anstalten von 1618 bis Ende des XIX. Jahrhunderts, I. Wien.

Wunder, Berndt [1981]. Der württembergische Personaladel (1806-1913). Zeitschrift für württembergische Landesgeschichte 40: 494-518.

Wurzbach, Constant von [1872]. Biographisches Lexicon des Kaiserthum Österreich, Bd. 23. Wien: Verlag der Universitäts-Buchdruckerei von L. C. Zamarski.

Zářický, Aleš [2004]. Ve stínu těžních věží. Historie dobývání kamenného uhlí v petřvaldské dílči pánvi od počátku prospektorské činnosti do roku 1906. Ostrava: Ostravská univerzita.

Županič, Jan - Fiala, Michal - Koblasa, Pavel (ed.) [2014]. Šlechtický archiv c. k. ministerstva vnitra Erbovní listiny Národního archivu, Státního oblastního archivu v Praze, Archivu hlavního města Prahy (dodatky), Archivu Národního muzea (dodatky). Praha: Agentura Pankrác.

Županič, Jan - Fiala, Michal [2017]. Nobilitas Iudaeorum. Židovská šlechta střední Evropy v komparativní perspektivě. Praha: Agentura Pankrác.

Županič, Jan [2006]. Nová šlechta Rakouského císařství. Praha: Agentura Pankrác.

Županič, Jan [2008]. Nobilitace spojené se světovou výstavou roku 1873. In. Brňovják, Jiří - Zářický, Aleš (ed.). Šlechtic podnikatelem, podnikatel šlechticem. Ostrava: Ostravská univerzita v Ostravě, s. 261-286.

Županič, Jan [2009]. Nobilitace žen v Rakouském císařství. In. Ambrožová, Hana a kol. Historik na Moravě. Brno: Matice Moravská.

Županič, Jan [2011]. Karlovská šlechta. Rakouské a uherské nobilitace ve světle materiálů kabinetní kanceláře Karla I. (IV.). In. Sborník archivních prací LXI (1): 3-114. 
Županič, Jan [2012]. Židovská šlechta podunajské monarchie. Mezi Davidovou hvězdou kř́žem. Praha: Nakladatelství Lidové noviny.

Županič, Jan [2015]. Proměna nobilitační politiky podunajské monarchie po roce 1848. Český časopis historický 117 (3/2019): 535-585.

Županič, Jan [2017]. Poslední rytíri monarchie. In. Kykal, Tomáš - Láník, Jaroslav a kol., Léta do pole okovaná, sv. II, 1915 - Noví nepřátelé, nové výzvy. Praha: Ministerstvo obrany České republiky - VHÚ Praha, s. 133-145.

Županič, Jan [2019a]. Nobilitierungspolitik der letzten Habsburger. Der neue Adel im Zeitalter Franz Josephs und Karls. Vierteljahrschrift für Sozial- und Wirtschaftsgeschichte, 106 (4): 473-518.

Županič, Jan [2019b]. Proměna vojenské šlechty za první světové války. In. Sborník archivních prací LXIX (1) 1: 87-137.

Jan Županič $\left({ }^{*} 1972\right)$ je profesorem obecných a světových dějin a působí na Filozofické fakultè Univerzity Karlovy. Zaměřuje se na studium vývoje elit v 19. a 20. století a proměnu aristokracie v moderní době. Je autorem řady odborných studií a několika monografí: např Šlechta na křižovatce. Lichtenštejnové, Schwarzenbergové a Colloredo-Mannsfeldové v 1. polovině 20. století (s V. Horčičkou, 2017); Nobilitas Iudaeorum. Židovská šlechta střední Evropy v komparativní perspektivě ( $\mathrm{M}$. Fialou); Židovská šlechta podunajské monarchie. Mezi Davidovou hvězdou a křrižem (2012); či Nová šlechta Rakouského císařství (2006). 